\title{
Elucidating trophic pathways in benthic deep-sea assemblages of the Mid-Atlantic Ridge north and south of the Charlie-Gibbs Fracture Zone
}

\author{
William D. K. Reid ${ }^{1, *}$, Ben D. Wigham ${ }^{1}$, Rona A. R. McGill' ${ }^{2}$ Nicholas V. C. Polunin ${ }^{1}$ \\ ${ }^{1}$ Ridley Building, School of Marine Science \& Technology, Newcastle University, Newcastle NE1 7RU, UK \\ ${ }^{2}$ NERC Life Sciences Mass Spectrometry Facility, Scottish Universities Environmental Research Centre, \\ East Kilbride G75 0QF, UK
}

\begin{abstract}
The Mid-Atlantic Ridge (MAR) is a topographically complex feature in the North Atlantic Ocean with little exploration of benthic fauna except in association with hydrothermal venting, resulting in the biodiversity and ecosystem functioning of the MAR benthos away from these sites remaining largely unknown. Stable isotope analysis of carbon, nitrogen and sulphur were undertaken on fauna collected north and south of the Charlie-Gibbs Fracture Zone, in areas believed to be devoid of hydrothermal venting, to investigate the trophodynamics of the benthic assemblage. $\delta^{13} \mathrm{C}$ and $\delta^{34} \mathrm{~S}$ values of the benthic and bentho-pelagic fauna indicated a dependence on photosynthetic primary production, with no influence from an unknown chemosynthetic source. A large trophic discrimination in $\delta^{13} \mathrm{C}$ between consumers and potential food sources (particulate organic matter and surficial sediments) suggested reworking of organic carbon before assimilation by benthic fauna. Interpretation of sediment $\delta^{15} \mathrm{~N}$ values was difficult as these ranged between -0.74 and $23.14 \%$, suggesting further work is required to understand nitrogen utilisation by benthic deposit feeders. Differences in trophic guilds (predators, predator-scavenger, surface deposit feeders, subsurface deposit feeders and suspension feeders) were evident for $\delta^{13} \mathrm{C}$ and $\delta^{15} \mathrm{~N}$, with the main difference between the mobile predators-scavengers and the benthic deposit feeders. Dividing the assemblage based on trophic guilds into food chains dependent on phytodetritus (deposit and suspension feeders) and predation-scavenging (fishes and crustaceans) resulted in strong positive correlations between $\delta^{15} \mathrm{~N}$ and $\delta^{13} \mathrm{C}$ at both stations. These reflected the 2 dominant trophic pathways organic matter passed through deposit feeders and predatory and scavenging deep-sea fishes and crustaceans.
\end{abstract}

KEY WORDS: Mid-ocean ridge - Bentho-pelagic coupling - Marine sediment - Food web · Nitrogen $\cdot$ Carbon

Resale or republication not permitted without written consent of the publisher

\section{INTRODUCTION}

The mid-ocean ridge (MOR) system is a conspicuous topographic feature in the deep sea, $60000 \mathrm{~km}$ long and is potentially distinct from similar depths on ocean margins because of the absence of terrigenous input (Juteau \& Maury 1999). Dissecting the world's ocean seafloor, they are regions where new oceanic crust forms and consequently contains large expan- ses of hard substrate, coupled with sediment-filled terraces creating a complex topography and hydrology. The Atlantic Ocean seafloor is divided in two by the Mid-Atlantic Ridge (MAR), which originates at the junction of the Gakkel Ridge northeast of Greenland and descends southwards, bisecting Iceland and the Azores, and continues toward the Bouvet Triple Junction at the interface between the Atlantic and Southern Oceans. The complex topography of the 
MAR means the benthos has remained largely unexplored, the exception being isolated areas of hydrothermal venting that are sustained by chemosynthesis (Gebruk et al. 1997). However, hydrothermal vent communities are not reflective of the ridge system as a whole (Copley et al. 1996, Bergstad et al. 2008), and the influence of chemosynthetic primary production along the ridge may only be small (Bergstad \& Godo 2003). Consequently, an understanding of the diversity, biomass and trophodynamics of the nonhydrothermal vent areas on the MAR is severely lacking.

Energy input sustaining benthic consumers on the MAR is expected to vary dramatically depending on whether the food source is chemosynthetic or photosynthetic in origin, and thus has implications for understanding the role MOR fauna play in carbon cycling. Primary production at hydrothermal vents is supported by chemoautotrophic bacteria which utilise reduced volatile compounds such as hydrogen sulphide as an electron donor to fix carbon from inorganic into organic compounds and thus provide nutrition for consumers (Van Dover 2000). Away from hydrothermal vents, the link between primary producers and consumers in the deep sea is very different. The main food source for non-vent benthic deep-sea fauna is photosynthetically derived organic matter from the surface waters, which sinks to the seafloor in the form of phytodetritus (Billett et al. 1983), consisting of a mix of dead phyto- and zooplankton, faecal pellets and bacteria (Gooday 2002). Bacteria and benthic invertebrates ingest, process and redistribute organic matter by incorporating it into biomass (Smith et al. 2002, Witte et al. 2003, Drazen et al. 2008a), forming a food chain largely dependent on phytodetritus. Further food sources arrive at the sea-floor as discrete food falls of marine carrion (Smith 1985, Tyler et al. 1993), bathypelagic fauna impinging on topographic features or vertically interconnecting food chains through the mesoand bathypelagic realms (Angel 1997). Mobile benthic and bentho-pelagic predators and scavengers consume these food sources and form the end point of a bathypelagic food chain.

Understanding energy flow and trophic ecology within the deep sea is important as this may influence community structure and biomass (Wei et al. 2010, Wolff et al. 2011), but it also provides information for building functional food web and carbon cycling models (Wei et al. 2010). Deep-sea predator-scavenger food chains become increasing linear with depth, suggesting stronger trophic connections and channelling of energy flow (Polunin et al. 2001).
The inclusion of deposit feeders in trophodynamic studies adds further complexity, as this may now include multiple trophic pathways that are less distinct and non-linear (Iken et al. 2001, Mincks et al. 2008). Bathypelagic fishes associated with the ridge crest are elevated in biomass between 1500 and $2300 \mathrm{~m}$ relative to the open-ocean above the adjacent abyssal plains, which may result in an enhanced pelagic food source and strong trophic connections to bentho-pelagic fishes (Sutton et al. 2008). The MAR is also hypothesised to be the largest area of benthic lower bathyal habitat, defined as depths from 800 to $3500 \mathrm{~m}$ by UNESCO (2009), in the North Atlantic, $>90 \%$ of which is covered in sediment (I. G. Priede pers. comm.). These 2 factors have potential implications for the transportation to and the processing of organic matter by the benthic community, whether it is reflected as a linear food web or separated into phytodetrital and predator-scavenger food chains.

Investigating the different trophic roles of deep-sea organisms in food webs is challenging in terms of sample collection and method of examination. Low sample sizes, damaged fauna and gut eversion, all make assessing deep-sea trophodynamics difficult. Stable isotope analysis (SIA) of carbon $\left({ }^{13} \mathrm{C}:{ }^{12} \mathrm{C}\right.$ expressed as $\left.\delta^{13} \mathrm{C}\right)$, nitrogen $\left({ }^{15} \mathrm{~N}:{ }^{14} \mathrm{~N}\right.$ expressed as $\left.\delta^{15} \mathrm{~N}\right)$ and sulphur $\left({ }^{34} \mathrm{~S}:{ }^{32} \mathrm{~S}\right.$ expressed as $\left.\delta^{34} \mathrm{~S}\right)$ measures material naturally incorporated into the organism's tissue, providing a temporally and spatially integrated analysis of the assimilated diet (Hesslein et al. 1993). Consumers show a trophic discrimination (or trophic shift) in the heavier isotope $\left({ }^{13} \mathrm{C},{ }^{15} \mathrm{~N}\right.$ and $\left.{ }^{34} \mathrm{~S}\right)$ compared to their food source as a result of isotopic discrimination occurring during a series of metabolic reactions. Trophic discrimination results in consumers being between 0 and $1.5 \%$ enriched in ${ }^{13} \mathrm{C}$ and ${ }^{34} \mathrm{~S}$ and 2.3 and $5 \%$ enriched in ${ }^{15} \mathrm{~N}$ relative to their food source (Peterson \& Fry 1987, Post 2002). Small trophic discriminations in stable carbon and sulphur isotopes allow them to be used in identifying energy sources, and when these are isotopically distinct multiple sources can be elucidated. In the case of $\delta^{34} \mathrm{~S}$, it can distinguish between chemosynthetic and photosynthetic primary production because photosynthetic primary production uses seawater sulphate $(\sim 19 \%)$ to produce organic sulphur compounds (Thode 1991, Connolly et al. 2004) while chemosynthetic primary production at hydrothermal vents uses sulphides that can range between -2.8 and 10\% (Shanks 2001, Reeves et al. 2011). The larger trophic discrimination in stable nitrogen isotopes helps to indicate the relative trophic position of an organism from a basal resource (Post 2002). 
The present study provides the first insight into the trophodynamics of a non-vent benthic MOR assemblage. The main aim of our study was to explore the potential trophic pathways supporting the benthic assemblages at 2 stations of the MAR. These stations lie north and south of the Charlie-Gibbs Fracture Zone (CGFZ), which defines the position of the Arctic Sub-Polar Front, and are therefore situated under different oceanographic regimes with contrasting surface primary production (Longhurst 2006, Martinez-Vicente et al. 2012). They are also under surface waters experiencing decreasing surface primary productivity as a result of increasing sea-surface temperatures (Tilstone et al. 2009). It is hypothesised that within the MAR benthic community there will be 2 distinct trophic pathways: one based on the downward flux of phytodetritus utilised by benthic deposit feeders and a second that utilises the elevated bathyal biomass present in association with the ridge (Sutton et al. 2008) and scavenging. The investigation will examine (1) stable carbon and nitrogen

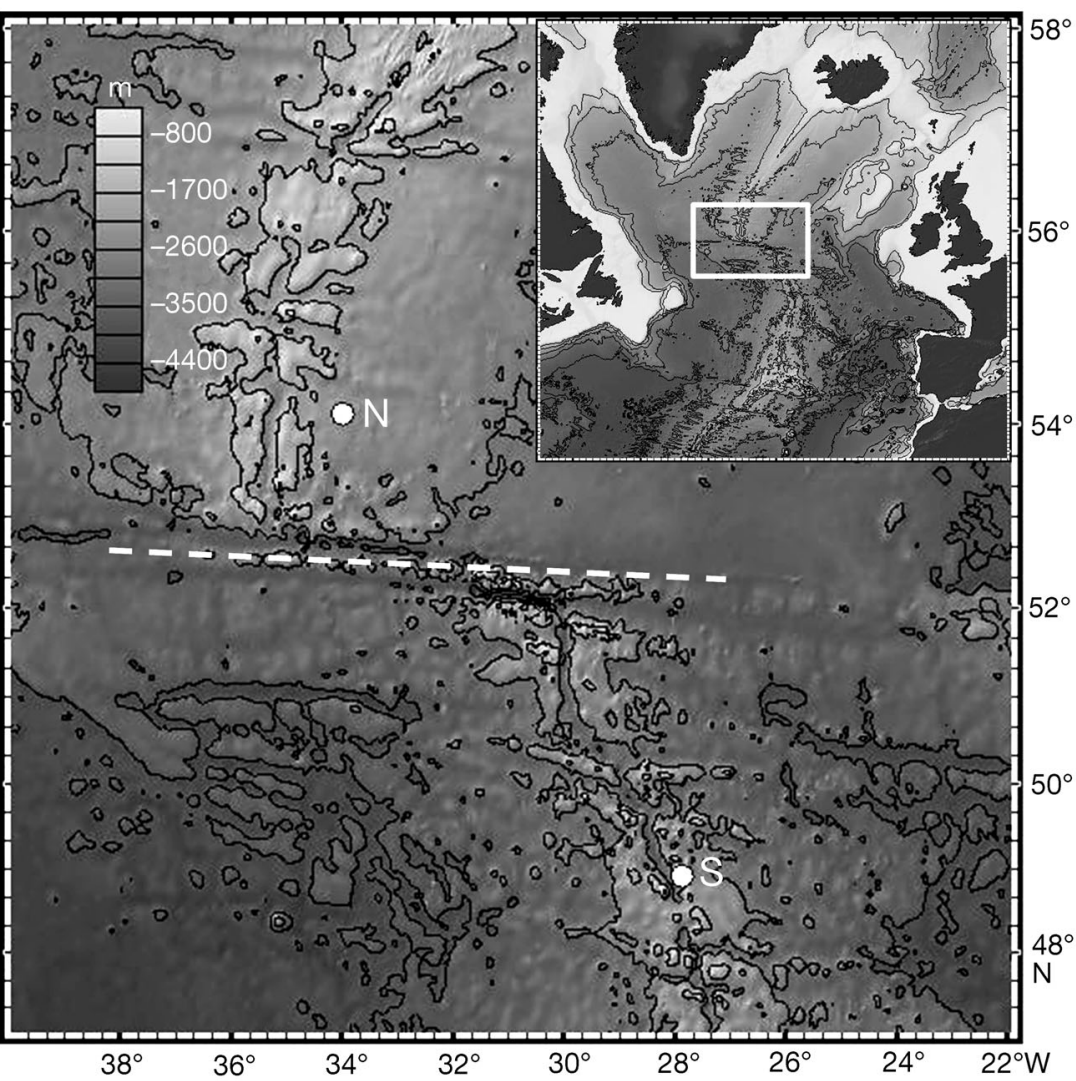

Fig. 1. Bathymetric map of the Mid-Atlantic Ridge. O: sampling stations north (N) and south (S) of the Charlie-Gibbs Fracture Zone (dashed white line). Inset: position of the study area in relation to the rest of the North Atlantic Ocean isotope values of sediment and partic-

ulate organic matter as potential food sources, (2) spatial and temporal differences in stable isotope values of potential food sources and benthic and bentho-pelagic consumers, (3) stable sulphur isotope values of benthic and bentho-pelagic consumers to indentify whether there is an input of chemosynthetic organic matter, (4) isotopic differences in trophic guilds, and (5) whether there is $>1$ food chain evident within the MAR benthic assemblage.

\section{MATERIALS AND METHODS}

\section{Study sites}

Two stations on the eastern axis of the MAR, north (Stn N) and south (Stn S) of the CGFZ, were sampled from onboard RRS 'James Cook' during the summers 2007 (13 July to 18 August) and 2009 (1 August to 9 September 2009) (Fig. 1). They were chosen as part of Natural Environment Research Council consortium grant ECOMAR. The overarching aim of the
ECOMAR project was to determine the local and regional impact of the MAR as a physical structure on the ecology of the North Atlantic Basin in terms of production, biomass and biodiversity from the surface to the deep-sea benthos. The stations are remote from any islands and seamounts, with no known hydrothermal activity, and are regarded as 'typical' ridge segments. These stations are located $\sim 690 \mathrm{~km}$ apart at depths between 2400 and $2750 \mathrm{~m}$.

\section{Sample collection and preparation}

A swath bathymetry survey of the stations was undertaken during the 2007 research survey to assess the bottom topography to find suitable ground for the sediment trap mooring and benthic sampling (Table 1). Benthic fauna were collected using a single warp semi-balloon otter trawl (OTSB), with a wing end spread of $8.6 \mathrm{~m}$ and a headrope height of $1.5 \mathrm{~m}$. Further details of the net configuration can be found in Merrett \& Marshall (1980). Scavenging 
Table 1. Stations (South $=\mathrm{S}_{;}$North $=\mathrm{N}$ ), dates, positions, depths and gear used to collect samples from the Mid-Atlantic Ridge in the summers of 2007 and 2009. OTSB: semi-balloon otter trawl

\begin{tabular}{|c|c|c|c|c|c|c|c|}
\hline \multirow[t]{2}{*}{ Station } & \multirow{2}{*}{$\begin{array}{l}\text { Sampling } \\
\text { gear }\end{array}$} & \multirow{2}{*}{$\begin{array}{c}\text { Deployment } \\
\text { date } \\
\text { (dd/mm/yyyy) }\end{array}$} & \multirow{2}{*}{$\begin{array}{l}\text { Depth } \\
\text { (m) }\end{array}$} & \multicolumn{2}{|c|}{ Start position } & \multicolumn{2}{|c|}{ End position } \\
\hline & & & & Latitude & Longitude & Latitude & Longitude \\
\hline $\mathrm{S}$ & OTSB & $21 / 07 / 2007$ & 2700 & $49^{\circ} 14.68^{\prime} \mathrm{N}$ & $27^{\circ} 42.31^{\prime} \mathrm{W}$ & $49^{\circ} 03.43^{\prime} \mathrm{N}$ & $27^{\circ} 53.86^{\prime} \mathrm{W}$ \\
\hline $\mathrm{S}$ & OTSB & $22 / 07 / 2007$ & 2718 & $48^{\circ} 54.59^{\prime} \mathrm{N}$ & $27^{\circ} 50.00^{\prime} \mathrm{W}$ & $49^{\circ} 15.85^{\prime} \mathrm{N}$ & $27^{\circ} 50.00^{\prime} \mathrm{W}$ \\
\hline S & Megacorer & $23 / 07 / 2009$ & 2763 & $49^{\circ} 05.42^{\prime} \mathrm{N}$ & $27^{\circ} 50.24^{\prime} \mathrm{W}$ & & \\
\hline $\mathrm{N}$ & OTSB & $10 / 08 / 2007$ & 2405 & $54^{\circ} 06.33^{\prime} \mathrm{N}$ & $33^{\circ} 58.27^{\prime} \mathrm{W}$ & $53^{\circ} 47.47^{\prime} \mathrm{N}$ & $34^{\circ} 02.89^{\prime} \mathrm{W}$ \\
\hline $\mathrm{N}$ & OTSB & $11 / 08 / 2007$ & 2410 & $54^{\circ} 05.68^{\prime} \mathrm{N}$ & $33^{\circ} 58.54^{\prime} \mathrm{W}$ & $53^{\circ} 46.94^{\prime} \mathrm{N}$ & $34^{\circ} 03.02^{\prime} \mathrm{W}$ \\
\hline $\mathrm{N}$ & OTSB & $12 / 08 / 2007$ & 2404 & $54^{\circ} 05.68^{\prime} \mathrm{N}$ & $33^{\circ} 58.54^{\prime} \mathrm{W}$ & $53^{\circ} 47.71^{\prime} \mathrm{N}$ & $34^{\circ} 02.83^{\prime} \mathrm{W}$ \\
\hline $\mathrm{N}$ & Amphipod trap & 09/08/2007 & & $54^{\circ} 04.08^{\prime} \mathrm{N}$ & $34^{\circ} 09.43^{\prime} \mathrm{W}$ & & \\
\hline $\mathrm{N}$ & Megacorer & $09 / 08 / 2007$ & 2500 & $54^{\circ} 00.65^{\prime} \mathrm{N}$ & $34^{\circ} 10.42^{\prime} \mathrm{W}$ & & \\
\hline $\mathrm{S}$ & $\begin{array}{l}\text { Sediment } \\
\text { trap mooring }\end{array}$ & $31 / 07 / 2008$ & 2503 & $49^{\circ} 02.60^{\prime} \mathrm{N}$ & $27^{\circ} 43.48^{\prime} \mathrm{W}$ & & \\
\hline S & OTSB & 10/08/2009 & 2700 & $48^{\circ} 58.73^{\prime} \mathrm{N}$ & $27^{\circ} 51.01^{\prime} \mathrm{W}$ & $49^{\circ} 11.14^{\prime} \mathrm{N}$ & $27^{\circ} 49.17^{\prime} \mathrm{W}$ \\
\hline $\mathrm{S}$ & OTSB & $10 / 08 / 2009$ & 2700 & $48^{\circ} 58.05^{\prime} \mathrm{N}$ & $27^{\circ} 51.06^{\prime} \mathrm{W}$ & $49^{\circ} 14.36^{\prime} \mathrm{N}$ & $27^{\circ} 49.29^{\prime} \mathrm{W}$ \\
\hline $\mathrm{S}$ & OTSB & 18/08/2009 & 2700 & $48^{\circ} 57.34^{\prime} \mathrm{N}$ & $27^{\circ} 49.83^{\prime} \mathrm{W}$ & $49^{\circ} 13.55^{\prime} \mathrm{N}$ & $27^{\circ} 50.92^{\prime} \mathrm{W}$ \\
\hline $\mathrm{S}$ & Megacorer & 07/08/2009 & 2720 & $49^{\circ} 05.39^{\prime} \mathrm{N}$ & $27^{\circ} 50.24^{\prime} \mathrm{W}$ & & \\
\hline $\mathrm{S}$ & Megacorer & 08/08/2009 & 2720 & $49^{\circ} 05.40^{\prime} \mathrm{N}$ & $27^{\circ} 50.22^{\prime} \mathrm{W}$ & & \\
\hline S & Megacorer & 08/08/2009 & 2720 & $49^{\circ} 05.40^{\prime} \mathrm{N}$ & $27^{\circ} 50.22^{\prime} \mathrm{W}$ & & \\
\hline
\end{tabular}

amphipods were sampled using a free-fall, baited amphipod trap. Catches were sorted on board to the lowest possible taxonomic resolution. Abundant organisms were selected for trophic analysis in 2007, and a broader range of samples was selected in 2009 to gain a better understanding of the wider community. Muscular tissue or body wall were dissected and frozen at $-80^{\circ} \mathrm{C}$ in glass vials. In order to obtain enough tissue mass for ophiuroids, amphipods and irregular sea urchins, arms, whole individuals and gonads, respectively, were dissected. No trawl samples were collected from the northern station in 2009 due to problems with the trawling gear.

Sediment cores were collected in 2007 and 2009 using a Bowers-Connolly megacorer fitted with eight $100 \mathrm{~mm}$ diameter coring tubes (Gage \& Bett 2005). Three undisturbed cores with intact sediment layers were selected for sampling at each station. Surface $(0$ to $5 \mathrm{~mm}$ ) and subsurface (5 to $10 \mathrm{~mm}$ ) sediments were collected and stored at $-80^{\circ} \mathrm{C}$ in glass vials for carbon and nitrogen SIA. Particulate organic matter (POM) was collected in sediment traps at $100 \mathrm{~m}$ above the seafloor at monthly intervals. Trap contents were preserved in formalin. Mobile organisms (e.g. pelagic copepods) were removed, and each bottle was split into a series of aliquots for analysis. Sediment traps were not deployed prior to sample collection in 2007, and, because no faunal samples were collected from the northern station in 2009, only samples from March to July from the southern station were analysed. Formalin preservation could not be avoided because the traps were deployed in a remote location for 12 mo periods. The $\delta^{13} \mathrm{C}$ and $\delta^{15} \mathrm{~N}$ values are reported with caution because formalin fixation can have a variable effect on stable isotope values (Bosley \& Wainright 1999, Kaehler \& Pakhomov 2001, Bicknell et al. 2011). Sediments were freeze dried, while POM was dried in an oven at $50^{\circ} \mathrm{C}$ until constant weight prior to homogenisation.

Faunal tissue was freeze dried and ground using a pestle and mortar and separated into aliquots for carbon, nitrogen and sulphur SIA. Aliquots for carbon SIA were lipid extracted because lipids are depleted in ${ }^{13} \mathrm{C}$ relative to protein and variation in lipid content between species can confound food web analysis when the $\delta^{13} \mathrm{C}$ values of source material are similar (Post et al. 2007). The samples were immersed in a 2:1 chloroform:methanol mix 20 times their sample volume, agitated for $30 \mathrm{~min}$ and then centrifuged at $3400 \mathrm{rpm}$ for $10 \mathrm{~min}$. The procedure was repeated up to 3 times or until the supernatant became clear after centrifuging. Samples were dried to constant weight at $50^{\circ} \mathrm{C}$ in an oven for $48 \mathrm{~h}$. Aliquots of fauna, POM and sediment were tested for carbonates prior to analysis with $0.1 \mathrm{~N} \mathrm{HCl}$. Bubbling indicated carbonates, and the sample was subsequently acidified by further addition of acid until the bubbling ceased. Samples were redried at $50^{\circ} \mathrm{C}$ for $48 \mathrm{~h}$. If the sample did not bubble no acidification was carried out.

Carbon, nitrogen and sulphur aliquots were weighed into separate tin capsules with the catalyst vanadium pentoxide added to the sulphur samples. Dual 
stable carbon and nitrogen isotope ratios were measured by continuous-flow isotope ratio mass spectrometry using a Costech Elemental Analyser interfaced with either a Thermo Finnigan Delta Plus XP Mass Spectrometer or a Thermo Finnigan Delta V Plus Mass Spectrometer (Natural Environment Research Council, Life Sciences Mass Spectrometry Facility, SUERC, East Kilbride). Two laboratory standards were analysed every 10 samples in each analytical sequence for linearity and drift corrections: paired alanine standards, of differing $\delta^{13} \mathrm{C}$ and $\delta^{15} \mathrm{~N}$, and an internal laboratory gelatine standard. Sulphur SIA was conducted by Iso-Analytical (Crewe) using a SERCON Elemental Analyser coupled to a Europa Scientific 20-20 mass spectrometer. Laboratory standards barium sulphate (2 sets of differing $\delta^{34} \mathrm{~S}$ ) and silver sulphide were used for calibration and drift correction. An internal standard of whale baleen was used for quality control ( $\mathrm{n}=7,16.87 \%$, $\pm 0.23 \mathrm{SD}$ ). Laboratory standards are traceable to international standards v-PDB (Pee Dee Belemnite), AIR (atmospheric nitrogen), NBS-127 (barium sulphate), IAEA-S-1 (silver sulphide) and IAEA-SO-5 (barium sulphate). An external standard of freezedried and ground white fish muscle (Antimora rostrata) was also analysed $\left(\delta^{13} \mathrm{C}, \mathrm{n}=30,-18.89 \pm\right.$ $0.07 \%$; $\delta^{15} \mathrm{~N}, \mathrm{n}=30,13.34 \pm 0.14 \%$; $\delta^{34} \mathrm{~S}, \mathrm{n}=8,19.03$ $\pm 0.73 \%$ )

\section{Statistical analyses}

Data were assessed for normality and variance using Shapiro-Wilk and Fligner-Killen tests or an F-test. Either Pearson's product momentum (r) or Spearman's rank correlation $\left(\mathrm{r}_{\mathrm{s}}\right)$, depending on normality was undertaken to assess the association between isotopic variables. Fauna were split into hypothesised trophic guilds after consulting published literature on morphology (e.g. Jangoux 1982, Billett 1991, Roberts \& Moore 1997), behaviour (e.g. Collins et al. 2005, Kemp et al. 2006) and diet (e.g. Mauchline \& Gordon 1984, Gartner et al. 1997, Howell et al. 2003). Statistical differences in trophic guilds, monthly differences in POM, and spatial and temporal differences in surface sediments were performed by 1-way ANOVA or a 2-sample $t$-test, when data were normally distributed with homogeneous variances. Tukey's honest significant differences (HSD) post hoc analysis was used to identify significant differences among groups. Welch's ANOVA or $t$-test was used when data had unequal variances but were normally distributed. Welch's tests use adjusted degrees of freedom to protect against Type I errors when variances are unequal (Quinn \& Keough 2002). Post hoc analysis in these circumstances was undertaken by a series of 2 sample $t$-tests with Bonferroni adjusted alpha level of $0.005(0.05 / 10)$ per test.

\section{RESULTS}

\section{Potential food sources}

There were spatial differences in the surface $(0$ to $5 \mathrm{~mm}$ : $t$-test, $t=-11.60, \mathrm{p}<0.05$ ) and subsurface (5 to $10 \mathrm{~mm}$ : $t$-test, $t=-19.34, \mathrm{p}<0.001)$ sediment layers, with Stn N depleted in ${ }^{13} \mathrm{C}$ compared to Stn S in 2007 (Fig. 2, Table 2). Temporal differences in the surface

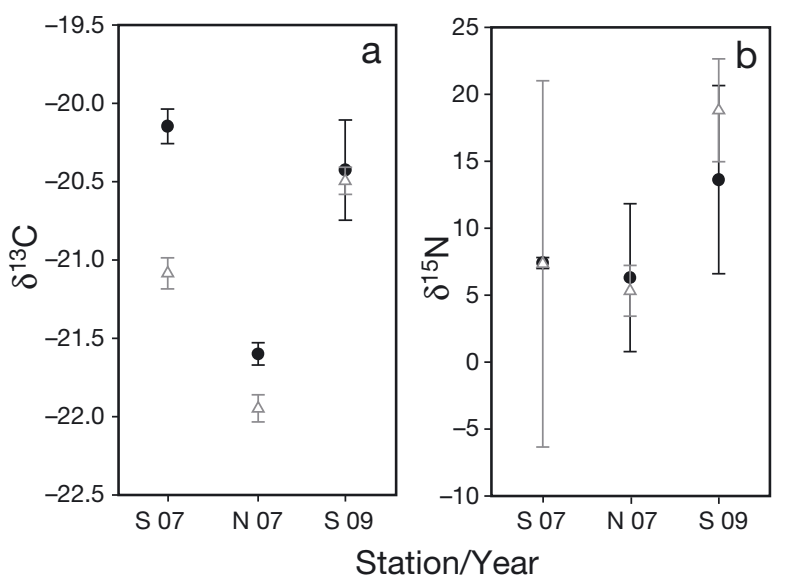

Fig. 2. (a) $\delta^{13} \mathrm{C}$ and (b) $\delta^{15} \mathrm{~N}$ of sediment, sampled at 0 to $5 \mathrm{~mm}(\Delta)$ and 5 to $10 \mathrm{~mm}(\bullet)$ depth horizons from cores collected from the Mid-Atlantic Ridge at the same southern station (S) in 2007 and 2009 and at the northern station (N) in 2007. Means \pm SD

Table 2. $\delta^{13} \mathrm{C}$ and $\delta^{15} \mathrm{~N}$ values (\%o) of surficial sediments and particulate organic matter collected from 2 stations (South $=\mathrm{S}$;

North $=\mathrm{N}$ ) on the Mid-Atlantic Ridge. Means \pm SD

\begin{tabular}{|lccccc|}
\hline $\begin{array}{l}\text { Sediment } \\
\text { source }\end{array}$ & \multicolumn{1}{c}{$\begin{array}{c}\text { Mtn } \\
\text { year }\end{array}$} & $\mathrm{n}$ & $\delta^{13} \mathrm{C} \pm \mathrm{SD}$ & $\delta^{15} \mathrm{~N} \pm \mathrm{SD}$ \\
\hline $\begin{array}{c}\text { Surface } \\
(0-5 \mathrm{~mm})\end{array}$ & $\mathrm{S}$ & 2007 & 3 & $-21.09 \pm 0.10$ & $7.34 \pm 13.68$ \\
& $\mathrm{~S}$ & 2009 & 3 & $-20.49 \pm 0.09$ & $18.80 \pm 3.84$ \\
Sub-surface & $\mathrm{N}$ & 2007 & 3 & $-21.95 \pm 0.09$ & $5.33 \pm 1.89$ \\
$(5-10 \mathrm{~mm})$ & $\mathrm{S}$ & 2007 & 3 & $-20.15 \pm 0.27$ & $7.41 \pm 0.41$ \\
& $\mathrm{~N}$ & 2007 & 3 & $-20.43 \pm 0.32$ & $13.62 \pm 7.01$ \\
Trap & $\mathrm{S}$ & Mar 2009 & 3 & $-24.47 \pm 0.02$ & $1.85 \pm 0.31$ \\
& $\mathrm{~S}$ & Apr 2009 & 3 & $-23.49 \pm 0.04$ & $0.98 \pm 0.15$ \\
& $\mathrm{~S}$ & May 2009 & 3 & $-22.76 \pm 0.04$ & $1.00 \pm 0.30$ \\
& $\mathrm{~S}$ & Jun 2009 & 3 & $-22.07 \pm 0.02$ & $1.80 \pm 0.09$ \\
& $\mathrm{~S}$ & Jul 2009 & 3 & $-21.69 \pm 0.04$ & $2.69 \pm 0.21$ \\
\hline
\end{tabular}


sediment layer of Stn S were evident ( $t$-test, $t=-7.91$, $\mathrm{p}<0.05)$, with the surface sediments collected in 2007 being ${ }^{13} \mathrm{C}$ depleted compared to those from 2009 (Fig. 2, Table 2). But there was no difference in $\delta^{13} \mathrm{C}$ of the subsurface sediment layer at Stn $\mathrm{S}$ between 2007 and 2009. Differences in the surface and subsurface layers at each station were also observed in 2007. The subsurface layer was enriched in ${ }^{13} \mathrm{C}$ compared to the surface layer at $\mathrm{Stn} \mathrm{S}(t$-test, $t$ $=-11.07, \mathrm{p}<0.001)$ and Stn $\mathrm{N}(t$-test, $t=-5.50, \mathrm{p}<$ 0.01); (Fig. 2, Table 2). There were no differences between the surface and subsurface layers in $\delta^{13} \mathrm{C}$ at Stn S in 2009.

The surface sediment layer had a greater spread in $\delta^{15} \mathrm{~N}$ at Stn S (-0.74 to $23.14 \%$ ) compared to Stn N (3.19 to $6.81 \%$ ) in 2007 ( $F$-test, $F=0.02$, p < 0.05). But mean $\delta^{15} \mathrm{~N}$ values of the surface layer did not differ between the 2 stations ( $p=0.91$ ) (Fig. 2, Table 2). In the subsurface layer, the spread of $\delta^{15} \mathrm{~N}$ values was greater at Stn N (0.39 to $11.34 \%$ o) compared to Stn S ( 7.00 to $7.83 \%$ ) ( $F$-test, $F=177.31, \mathrm{p}<0.01)$. Although there was still no between-station difference in $\delta^{15} \mathrm{~N}$ ( $p=0.76$ ) (Fig. 2, Table 2). Temporal differences at Stn S were observed in the subsurface layer, with a greater spread of $\delta^{15} \mathrm{~N}$ values observed in 2009 (Ftest, $F=0.035, \mathrm{p}<0.05)$, but there was no difference in the mean values $(\mathrm{p}=0.26)$. There were differences in the spread of $\delta^{15} \mathrm{~N}$ between the surface and subsurface layers at Stn S in 2007 ( $F$-test, $F=108.84, p$ $<0.01)$, but there was no difference in the mean $\delta^{15} \mathrm{~N}$ values $(\mathrm{p}=0.99)$. The surface and subsurface layers did not differ in $\delta^{15} \mathrm{~N}$ at Stn $\mathrm{N}$ in 2007 ( $\mathrm{p}=0.79$ ), nor at Stn $\mathrm{S}$ in $2009(\mathrm{p}=0.32)$.

Sediment trap POM $\delta^{13} \mathrm{C}$ differed among months $\left(\right.$ ANOVA, $\left.F_{4,10}=3198.2, \mathrm{p}<0.001\right)$, with all $5 \mathrm{mo}$ being different (Tukey's HSD, $\mathrm{p}<0.05$ ). Samples became increasingly enriched in ${ }^{13} \mathrm{C}$ from March to July ( -24.47 to $-21.69 \%$ ), but were consistently depleted in ${ }^{13} \mathrm{C}$ relative to the surface sediment layer (Table 2). $\delta^{15} \mathrm{~N}$ showed differences among months (ANOVA, $F_{4,10}=28.39, \mathrm{p}<0.001$ ), with values ranging from $0.98 \%$ (April) to $2.69 \%$ (July) and no consistent temporal pattern (Table 2).

\section{Spatial and temporal differences in trophic assemblages and fauna}

Mean $\delta^{13} \mathrm{C}$ was greater at Stn $\mathrm{S}$ compared to Stn $\mathrm{N}$ in 2007 ( $t$-test, $t=-4.86, \mathrm{p}<0.001) . \delta^{13} \mathrm{C}$ values $( \pm \mathrm{SD})$ were lowest in the decapod Acanthephyra sp. $(-18.43 \pm 0.42 \%)$ and the fish Bathylagus euryops $(-18.83 \pm 0.26 \%)$ and highest in the asteroids Pluto- naster sp. $(-14.55 \pm 0.53 \%)$ and Bathybiaster vexillifer $(-15.88 \pm 0.18 \%$ o) at Stn $\mathrm{S}$ and $\mathrm{Stn} \mathrm{N}$, respectively (Fig. 3a,b, Tables $3 \& 4$ ). Mean $\delta^{13} \mathrm{C}$ ranged between $-18.93 \pm 0.26 \%$ in the lophogastrid Gnathophausia zoea and $-14.34 \pm 0.31 \%$ in Plutonaster sp. at Stn $\mathrm{S}$ in 2009 (Fig. 4, Table 5).

Mean $\delta^{15} \mathrm{~N}$ did not differ between Stn S and Stn N in 2007 ( $\mathrm{p}=0.63) . \delta^{15} \mathrm{~N}$ was lowest in the holothurians Staurocucumis abyssorum (7.92 $\pm 0.28 \%$ ) and Peniagone azorica $(7.78 \pm 0.37 \%$ o), whereas the brisingid Freyella sp. (14.02 $\pm 0.08 \%$ o) and sipunculan Sipunculus norvegicus $(16.18 \pm 0.34 \%$ o) had the highest values, at Stn $\mathrm{S}$ and Stn N, respectively (Fig. 3a,b, Tables $3 \& 4$ ). Mean $\delta^{15} \mathrm{~N}$ ranged between $7.73 \pm$ $0.15 \%$ and $15.78 \pm 1.43 \%$ at Stn S in 2009 in the holothurians $S$. abyssorum and Molpadia musculus (Fig. 4, Table 5).

Mean $\delta^{34} \mathrm{~S}$ did not differ between Stn $\mathrm{S}$ and Stn $\mathrm{N}$ in 2007 ( $p=0.47$ ). The grenadier Coryphaenoides armatus (18.01 $\pm 1.33 \%$ ) and decapod Glyphocrangon sculpta (16.92 $\pm 1.64 \%$ ) had the lowest $\delta^{34} \mathrm{~S}$ values, while the asteroid Hymenaster membranaceus (21.10 $\pm 0.42 \%$ ) and echinoid Urechinus naresianus (21.92 \pm $0.08 \%$ ) had the highest $\delta^{34} \mathrm{~S}$ values at Stn $\mathrm{S}$ and Stn N, respectively (Fig. 3c,d, Tables 3 \& 4).

Spatial and temporal variability in $\delta^{13} \mathrm{C}$ and $\delta^{15} \mathrm{~N}$ were examined for fauna, which were the same between stations. Consistently higher $\delta^{13} \mathrm{C}$ values at Stn S compared to Stn N (t-test, p < 0.05) were observed in the holothurian Benthothuria funebris, decapods Glyphocrangon sculpta and Stereomastis nana, and fishes Coryphaenoides armatus, C. brevibarbis and Halosauropsis macrochir. Spatial differences in $\delta^{15} \mathrm{~N}$ were observed in 3 species. $G$. sculpta had lower $\delta^{15} \mathrm{~N}$ at Stn S compared to Stn N, while both $C$. brevibarbis and $S$. nana had higher $\delta^{15} \mathrm{~N}$ at Stn $\mathrm{S}$ compared to Stn $\mathrm{N}$ (t-test, p < 0.05). Since there was only 1 sample of $S$. nana collected at Stn S in 2007, this test should be treated with caution. There were temporal decreases in $\delta^{13} \mathrm{C}$ between 2007 and 2009 at Stn S for B. funebris and $C$. brevibarbis ( $t$-test, $\mathrm{p}<0.05)$, while $\delta^{13} \mathrm{C}$ increased between 2007 and 2009 in the anthozoan Anthomastus agaricus. There were no temporal differences in $\delta^{15} \mathrm{~N}$ values at $\mathrm{Stn} \mathrm{S}$.

\section{Mid-Atlantic Ridge trophic guilds}

Trophic guilds differed in $\delta^{13} \mathrm{C}$ within all stations (ANOVA, south 2007, $F_{4,16}=4.17, \mathrm{p}<0.05$; ANOVA, south 2009, $F_{4,33}=13.11, \mathrm{p}<0.001$; ANOVA, north $\left.2007, F_{3,19}=9.37, \mathrm{p}<0.001\right)$. At Stn $\mathrm{S}$ in 2007 the only 

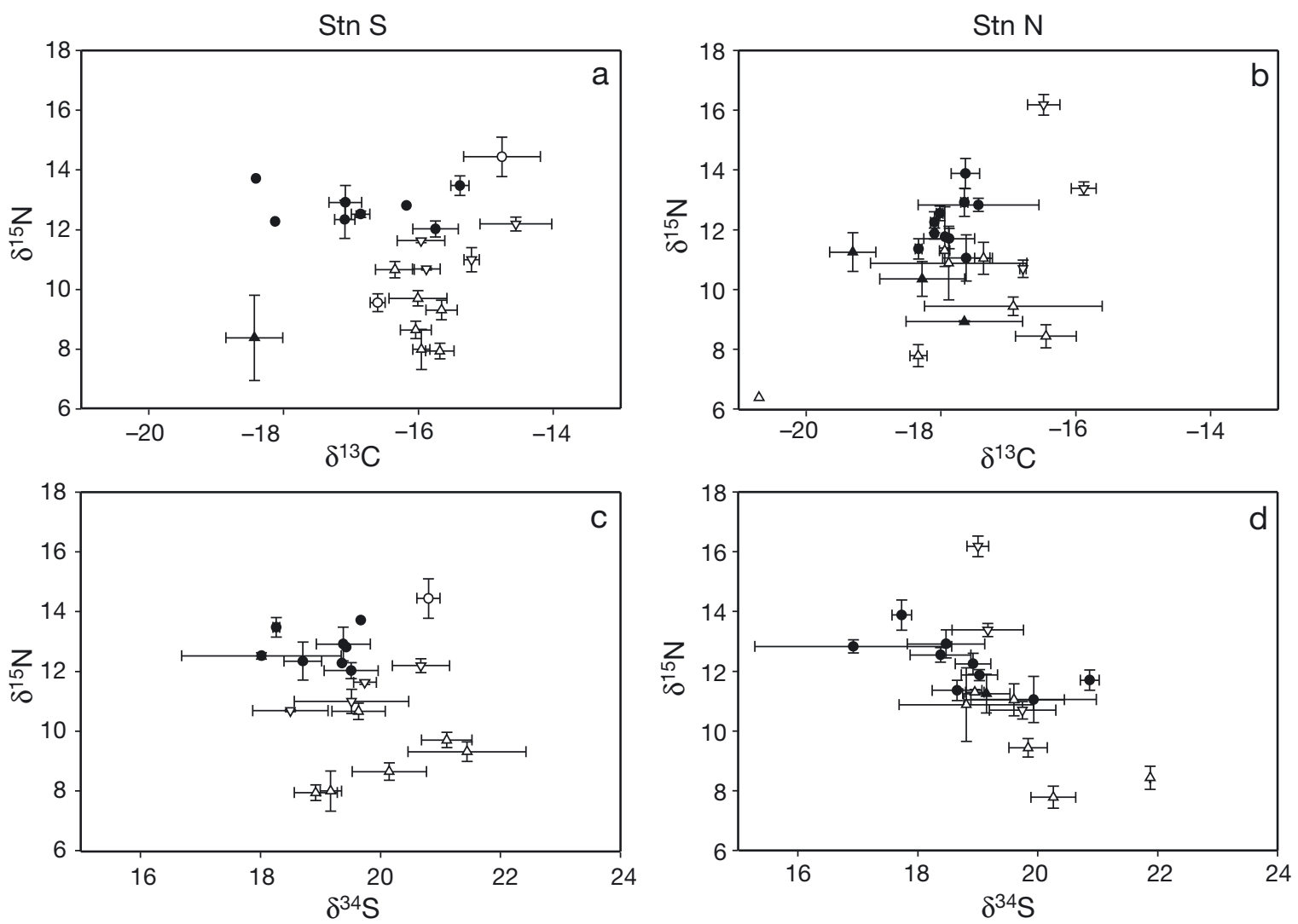

Fig. 3. (a,b) $\delta^{15} \mathrm{~N}$ and $\delta^{13} \mathrm{C}$, and $(\mathrm{c}, \mathrm{d}) \delta^{15} \mathrm{~N}$ and $\delta^{34} \mathrm{~S}$ of predators $(\mathbf{\Delta})$, predator-scavengers $(\boldsymbol{\bullet})$, surface deposit feeders $(\Delta)$, subsurface deposit feeders $(\nabla)$ and suspension feeders $(O)$ from the southern station $(\mathrm{a}, \mathrm{c})$ and northern station $(\mathrm{b}, \mathrm{d})$ of the Mid-Atlantic Ridge collected in 2007. Open symbols = fauna utilising the phytodetritus food chain; solid symbols = fauna utilising the predator-scavenger food chain. Means $\pm 1 \mathrm{SD}$

difference in trophic guilds was between predators (P) and subsurface deposit feeders (SSDF), although there was only 1 species represented within the predator trophic guild. In 2009, at Stn S P and predator-scavengers (PS) had lower $\delta^{13} \mathrm{C}$ than surface deposit feeders (SDF), SSDF and suspension feeders (SF) (Tukey HSD, p < 0.05), while there were no differences between the trophic guilds SDF, SSDF and SF. In contrast to Stn $\mathrm{S}$, the northern trophic guilds $\mathrm{P}$, PS and SDF were not different from each other, but had lower $\delta^{15} \mathrm{~N}$ values compared to SSDF (Tukey HSD, $p<0.05) . \delta^{34}$ S did not differ among trophic guilds within either station (ANOVA south 2007, p = 0.12; north 2007, $\mathrm{p}=0.43$ ).

$\delta^{15} \mathrm{~N}$ values of the trophic guilds differed within all stations (Welch's ANOVA, south 2007, $F_{4,3.7}=15.44, \mathrm{p}$ $<0.05$; ANOVA, south 2009, $F_{4,33}=8.85, \mathrm{p}<0.001$; ANOVA, north 2007, $F_{3,18}=6.40, \mathrm{p}<0.01$ ). The $\mathrm{P}$ trophic guild had lower $\delta^{15} \mathrm{~N}$ values than PS at Stn $\mathrm{S}$ in 2007 (Bonferroni adjusted $t$-test, $\mathrm{p}<0.005$ ), but was similar to PS in $\delta^{15} \mathrm{~N}$ at Stn S in 2009 and Stn N in 2007 (Tukey HSD, $\mathrm{p}=0.07$ ). $\mathrm{P}$ also had lower $\delta^{15} \mathrm{~N}$ values than SSDF at Stn S in 2007 (Bonferroni adjusted $t$ - test, $\mathrm{p}<0.005$ ) and 2009 (Tukey HSD, $\mathrm{p}<0.05$ ), as well as at Stn N (Tukey HSD, $p<0.05$ ). SDF had lower $\delta^{15} \mathrm{~N}$ values than PS and SSDF at Stn S in 2007 (Bonferroni adjusted $t$-test, $\mathrm{p}<0.005$ ) and 2009 (Tukey HSD, p < 0.05) and at Stn N (Tukey HSD, p < 0.05). Taken together with $\delta^{13} \mathrm{C}$, the $\delta^{15} \mathrm{~N}$ post hoc analysis suggested increasing isotopic values from $\mathrm{P}$ to PS and from SDF to SSDF, which illustrates a hierarchical pattern in trophic structure for predatory and deposit feeding organisms that was broadly similar between stations and years (Figs. 3a,b \& 4).

\section{Linearity of trophic assemblages}

There were no significant relationships at Stn $\mathrm{S}$ between $\delta^{15} \mathrm{~N}$ and $\delta^{13} \mathrm{C}$ across all species within each trophic assemblage $(2007, \mathrm{p}=0.39 ; 2009, \mathrm{p}=0.98)$ or between $\delta^{15} \mathrm{~N}$ and $\delta^{34} \mathrm{~S}(2007, \mathrm{p}=0.71)$. However, at Stn $\mathrm{N}$, relationships between $\delta^{15} \mathrm{~N}$ and $\delta^{13} \mathrm{C}(\mathrm{r}=0.43, \mathrm{p}$ $<0.01)$ and $\delta^{15} \mathrm{~N}$ and $\delta^{34} \mathrm{~S}(\mathrm{r}=-0.35, \mathrm{p}<0.01)$ were significant. The assemblages were split into 2 groups according to whether they were dependent on phyto- 
Table 3. $\delta^{13} \mathrm{C}, \delta^{15} \mathrm{~N}$ and $\delta^{34} \mathrm{~S}$ values (\%o) of benthic and bentho-pelagic fish and invertebrates collected in 2007 at the southern Mid-Atlantic Ridge station. Trophic guild abbreviations refer to suspension feeders (SF), surface deposit feeders (SDF), subsurface deposit feeders (SSDF), predators (P) and predator-scavengers (PS). Means \pm SD

\begin{tabular}{|c|c|c|c|c|c|c|}
\hline Taxon & Species & Trophic guild & $\mathrm{N}$ & $\delta^{13} \mathrm{C} \pm \mathrm{SD}$ & $\delta^{15} \mathrm{~N} \pm \mathrm{SD}$ & $\delta^{34} \mathrm{~S} \pm \mathrm{SD}$ \\
\hline \multicolumn{7}{|l|}{ Cnidaria } \\
\hline Anthozoa & Anthomastus agaricus & $\mathrm{SF}$ & 3 & $-16.60 \pm 0.11$ & $9.56 \pm 0.30$ & $19.35 \pm 0.1$ \\
\hline \multicolumn{7}{|l|}{ Echinodermata } \\
\hline \multirow[t]{5}{*}{ Asteroidea } & Hyphalaster inermis & SSDF & 3 & $-15.96 \pm 0.02$ & $10.69 \pm 0.03$ & $19.59 \pm 0.19$ \\
\hline & Porcellanaster cerulus & SSDF & 3 & $-15.88 \pm 0.21$ & $11.63 \pm 0.07$ & $19.74 \pm 0.19$ \\
\hline & Plutonaster sp. & SSDF & 3 & $-14.55 \pm 0.53$ & $12.19 \pm 0.23$ & $20.67 \pm 0.48$ \\
\hline & Hymenaster membranaceus & $\mathrm{SDF}$ & 3 & $-16.01 \pm 0.43$ & $9.70 \pm 0.26$ & $21.10 \pm 0.42$ \\
\hline & Freyella sp. & $\mathrm{SF}$ & 3 & $-14.76 \pm 0.57$ & $14.02 \pm 0.08$ & $20.80 \pm 0.19$ \\
\hline \multirow[t]{5}{*}{ Holothuroidea } & Staurocucumis abyssorum & SDF & 3 & $-16.59 \pm 1.77$ & $7.92 \pm 0.28$ & $18.92 \pm 0.36$ \\
\hline & Benthothuria funebris & SDF & 3 & $-15.21 \pm 0.12$ & $10.99 \pm 0.40$ & $19.52 \pm 0.95$ \\
\hline & Benthodytes gosarsi & $\mathrm{SDF}$ & 3 & $-15.66 \pm 0.23$ & $9.31 \pm 0.33$ & $21.44 \pm 0.98$ \\
\hline & Peniagone sp. A & SDF & 3 & $-15.95 \pm 0.13$ & $7.99 \pm 0.68$ & $19.17 \pm 0.18$ \\
\hline & Peniagone longipapillata & $\mathrm{SDF}$ & 3 & $-16.04 \pm 0.23$ & $8.65 \pm 0.29$ & $20.14 \pm 0.62$ \\
\hline \multicolumn{7}{|l|}{ Crustacea } \\
\hline \multirow[t]{5}{*}{ Decapoda } & Acanthephyra sp. & $\mathrm{P}$ & 3 & $-18.43 \pm 0.42$ & $8.38 \pm 1.43$ & $18.25 \pm 0.70$ \\
\hline & Glyphocrangon sculpta & SDF-PS & 3 & $-15.75 \pm 0.06$ & $12.02 \pm 0.27$ & $19.51 \pm 0.45$ \\
\hline & Munidopsis rostrata & $\mathrm{SDF}-\mathrm{PS}$ & 3 & $-16.35 \pm 0.29$ & $10.66 \pm 0.27$ & $19.63 \pm 0.44$ \\
\hline & Stereomastis nana & PS & 1 & -16.18 & 12.81 & 19.67 \\
\hline & Willemoesia forceps & PS & 1 & -18.41 & 13.72 & 19.43 \\
\hline \multicolumn{7}{|l|}{ Pisces } \\
\hline \multirow[t]{5}{*}{ Osteichthyes } & Antimora rostrata & PS & 1 & -18.12 & 12.28 & 19.36 \\
\hline & Coryphaenoides armatus & PS & 3 & $-16.86 \pm 0.14$ & $12.52 \pm 0.11$ & $18.01 \pm 1.33$ \\
\hline & Coryphaenoides brevibarbis & PS & 3 & $-17.09 \pm 0.15$ & $12.34 \pm 0.63$ & $18.70 \pm 0.32$ \\
\hline & Halosauropsis macrochir & PS & 3 & $-17.08 \pm 0.04$ & $12.90 \pm 0.56$ & $19.38 \pm 0.45$ \\
\hline & Polyacanthonotus challengeri & PS & 2 & $-15.38 \pm 0.14$ & $13.47 \pm 0.33$ & $18.26 \pm 0.06$ \\
\hline
\end{tabular}

detritus (SDF, SSDF and SF), or were mobile predators and scavengers (P and PS) (Figs. 3 \& 4). For the phytodetritus-dependent group, there were significant relationships between $\delta^{15} \mathrm{~N}$ and $\delta^{13} \mathrm{C}\left(2007, \mathrm{r}_{\mathrm{s}}=0.46, \mathrm{p}\right.$ $\left.<0.01 ; 2009, \mathrm{r}_{\mathrm{s}}=0.24, \mathrm{p}<0.05\right)$, but not between $\delta^{15} \mathrm{~N}$ and $\delta^{34} \mathrm{~S}(2007, \mathrm{p}=0.14)$ at $\mathrm{Stn} \mathrm{S}$. While at Stn $\mathrm{N}$ there were relationships between $\delta^{15} \mathrm{~N}$ and $\delta^{13} \mathrm{C}\left(\mathrm{r}_{\mathrm{s}}=0.68\right.$, $\mathrm{p}<0.001)$ and between $\delta^{15} \mathrm{~N}$ and $\delta^{34} \mathrm{~S}\left(\mathrm{r}_{\mathrm{s}}=-0.44\right.$, $\mathrm{p}<0.01)$. For the predator-scavenger group, at $\mathrm{Stn} \mathrm{S}$, there were relationships between $\delta^{15} \mathrm{~N}$ and $\delta^{13} \mathrm{C}$ in $2009\left(\mathrm{r}_{\mathrm{s}}=0.64, \mathrm{p}<0.001\right)$, but not in $2007(\mathrm{p}=0.15)$. There was also no significant relationship between $\delta^{15} \mathrm{~N}$ and $\delta^{34} \mathrm{~S}$ at $\mathrm{Stn} \mathrm{S}$ in $2007(\mathrm{p}=0.45)$. At Stn $\mathrm{N}$ the predator-scavenger group showed relationships between $\delta^{15} \mathrm{~N}$ and $\delta^{13} \mathrm{C}\left(\mathrm{r}_{\mathrm{s}}=0.40, \mathrm{p}<0.05\right)$ and between $\delta^{15} \mathrm{~N}$ and $\delta^{34} \mathrm{~S}\left(\mathrm{r}_{\mathrm{s}}=-0.43, \mathrm{p}<0.01\right)$.

\section{DISCUSSION}

Carbon and sulphur stable isotopic data indicated that the benthic assemblages at the 2 MAR stations appear to be supported by photosynthetic primary production. This accords with the range of $\delta^{13} \mathrm{C}$ values from other deep-sea systems where there is no energy input from chemosynthetic primary production, including abyssal benthic communities of the North Atlantic ( -23 to $-13 \%$; Iken et al. 2001) and North Pacific (-21 to $-17 \%$; Drazen et al. 2008b), continental slopes of the Mediterranean (-22 to $-16 \%$; Polunin et al. 2001) and the high Arctic ( -23 to $-16 \%$; Bergmann et al. 2009). However, $\delta^{13} \mathrm{C}$ values of hydrothermal vent fauna can cover the same $\delta^{13} \mathrm{C}$ range as non-vent fauna, making interpretation of carbon isotopic values ambiguous (Erickson et al. 2009). This is pertinent on MOR where vent organic matter entrained in hydrothermal plumes can be found settling $2 \mathrm{~km}$ away from the venting source (Roth \& Dymond 1989), bathypelagic biomass in association with the hydrothermal plume can be enhanced (Burd et al. 1992) and consumers at inactive chemosynthetic sites can potentially utilise organic sulphur compounds derived from sulphide of hydrothermal vent origin that has persisted within the sediment (Erickson et al. 2009). Macro-consumers feeding on photosynthetically derived 
Table $4 . \delta^{13} \mathrm{C}, \delta^{15} \mathrm{~N}$ and $\delta^{34} \mathrm{~S}$ values (\%o) of benthic and benthopelagic fish and invertebrates collected in 2007 at the northern Mid-Atlantic Ridge station. Trophic guild abbreviations see Table 3. Means \pm SD

\begin{tabular}{|c|c|c|c|c|c|c|}
\hline Taxonomic group & Species & rophic guild & $\mathrm{N}$ & $\delta^{13} \mathrm{C} \pm \mathrm{SD}$ & $\delta^{15} \mathrm{~N} \pm \mathrm{SD}$ & $\delta^{34} \mathrm{~S} \pm \mathrm{SD}$ \\
\hline \multicolumn{7}{|l|}{ Foraminifera } \\
\hline Polythalamea & Rhizammina sp. & $\mathrm{SDF}$ & 1 & -20.70 & 6.38 & 17.77 \\
\hline \multicolumn{7}{|l|}{ Echinodermata } \\
\hline \multirow[t]{2}{*}{ Asteroidea } & Bathybiaster vexillifer & SSDF & 6 & $-15.88 \pm 0.18$ & $13.18 \pm 0.22$ & $19.17 \pm 0.60$ \\
\hline & Hymenaster cf. coccinatus & $\mathrm{SDF}$ & 3 & $-16.01 \pm 0.43$ & $9.42 \pm 0.26$ & $19.84 \pm 0.32$ \\
\hline Echinoidea & Urechinus naresianus & SDF & 3 & $-16.69 \pm 0.53$ & $9.03 \pm 1.07$ & $21.92 \pm 0.08$ \\
\hline \multirow[t]{3}{*}{ Holothuroidea } & Benthothuria funebris & SDF & 3 & $-16.78 \pm 0.05$ & $10.70 \pm 0.29$ & $19.74 \pm 0.55$ \\
\hline & Paelopatides grisea & SDF & 3 & $-17.37 \pm 0.13$ & $11.05 \pm 0.53$ & $19.60 \pm 0.84$ \\
\hline & Peniagone azorica & SDF & 5 & $-18.36 \pm 0.23$ & $7.68 \pm 0.30$ & $20.26 \pm 0.37$ \\
\hline Ophuiroidea & Ophuiroid sp. & SDF & 2 & $-17.94 \pm 0.08$ & $11.35 \pm 0.02$ & $18.95 \pm 0.15$ \\
\hline \multicolumn{7}{|l|}{ Crustacea } \\
\hline Amphipoda & Eurythenes gryllus & PS & 3 & $-17.72 \pm 0.49$ & $10.15 \pm 1.02$ & $19.93 \pm 1.05$ \\
\hline \multirow[t]{4}{*}{ Decapoda } & Acanthephyra sp. & $\mathrm{P}$ & 2 & $-18.82 \pm 0.67$ & $8.93 \pm 0.02$ & $18.33 \pm 0.14$ \\
\hline & Glyphocrangon sculpta & SDF-PS & 2 & $-17.44 \pm 0.90$ & $12.83 \pm 0.22$ & $16.92 \pm 1.64$ \\
\hline & Munidopsis bermudezi & SDF-PS & 2 & $-17.88 \pm 1.16$ & $10.88 \pm 1.23$ & $18.81 \pm 1.12$ \\
\hline & Stereomastis nana & PS & 3 & $-17.88 \pm 0.38$ & $11.81 \pm 0.24$ & $20.87 \pm 0.15$ \\
\hline Lophogastrida & Gnathophausia zoea & $\mathrm{P}$ & 3 & $-18.28 \pm 0.63$ & $10.35 \pm 0.58$ & $18.52 \pm 0.17$ \\
\hline \multicolumn{7}{|l|}{ Sipuncula } \\
\hline Sipunculidea & Sipunculus norvegicus & SSDF & 3 & $-16.48 \pm 0.24$ & $16.18 \pm 0.34$ & $19.00 \pm 0.18$ \\
\hline \multicolumn{7}{|l|}{ Pisces } \\
\hline \multirow[t]{8}{*}{ Osteichthyes } & Antimora rostrata & PS & 3 & $-18.10 \pm 0.03$ & $11.87 \pm 0.19$ & $19.03 \pm 0.30$ \\
\hline & Bathylagus euryops & $\mathrm{P}$ & 3 & $-19.31 \pm 0.34$ & $11.25 \pm 0.65$ & $19.14 \pm 0.40$ \\
\hline & Bathysaurus ferox & PS & 3 & $-17.64 \pm 0.21$ & $13.88 \pm 0.50$ & $17.73 \pm 0.16$ \\
\hline & Coryphaenoides armatus & PS & 3 & $-18.02 \pm 0.05$ & $12.55 \pm 0.54$ & $18.83 \pm 0.50$ \\
\hline & Coryphaenoides brevibarbis & PS & 3 & $-18.33 \pm 0.05$ & $11.36 \pm 0.34$ & $18.65 \pm 0.41$ \\
\hline & Coryphaenoides mediterraneus & US PS & 2 & $-18.10 \pm 0.06$ & $12.25 \pm 0.35$ & $18.92 \pm 0.30$ \\
\hline & Halosauropsis macrochir & PS & 3 & $-17.56 \pm 0.05$ & $12.91 \pm 0.47$ & $18.47 \pm 0.65$ \\
\hline & Histiobranchius bathybius & PS & 2 & $-17.94 \pm 0.01$ & $11.77 \pm 1.00$ & $17.98 \pm 0.41$ \\
\hline
\end{tabular}

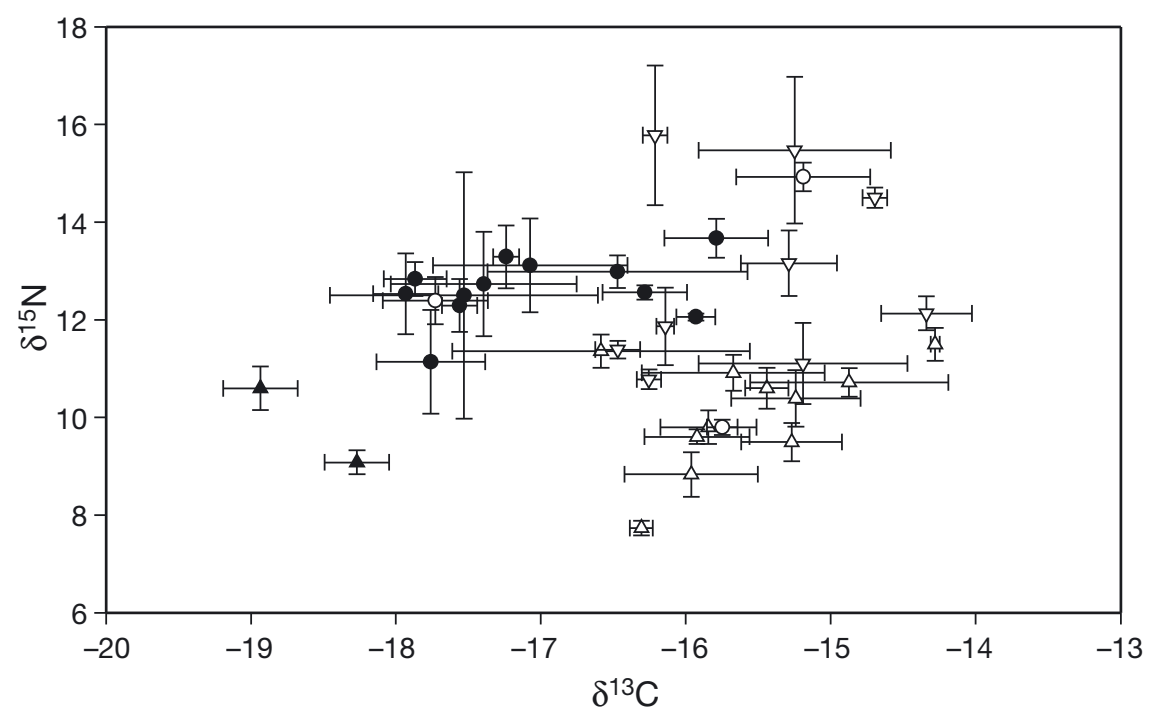

Fig. 4. $\delta^{15} \mathrm{~N}$ and $\delta^{13} \mathrm{C}$ of predators $(\boldsymbol{\Delta})$, predator-scavengers $(\bullet)$, surface deposit feeders $(\Delta)$, subsurface deposit feeders $(\nabla)$ and suspension feeders $(O)$ collected in 2009 from the southern Mid-Atlantic Ridge station. Open symbols = fauna utilising the phytodetritus food chain; solid symbols = fauna utilising the predator-scavenger food chain. Means $\pm 1 \mathrm{SD}$ organic sulphur compounds have $\delta^{34} \mathrm{~S}$ values ranging from 16 to $19 \%$ (Fry 1988), while organisms consuming organic sulphur compounds of hydrothermal vent origin have $\delta^{34} \mathrm{~S}$ values between -9 and $10 \%$ (Erickson et al. 2009, Fabri et al. 2011). The MAR consumers fall within the former range, confirming these stations were dependent on photosynthetic primary production and not influenced by unknown chemosynthetic sources that were transported to or persisted within the sediment.

The pathways by which organic matter reaches the seafloor, for example as phytodetritus or vertically interconnecting food chains, will have implications for how it is utilised and may be reflected in the stable isotope values of the MAR benthic macro-consumers. Mediterranean deep-water bentho-pelagic 
Table 5. $\delta^{13} \mathrm{C}$ and $\delta^{15} \mathrm{~N}$ values (\%) of benthic and benthopelagic fish and invertebrates collected in 2009 at the southern Mid-Atlantic Ridge station. Trophic guild abbreviations see Table 3. Means \pm SD

\begin{tabular}{|c|c|c|c|c|c|}
\hline Taxon & Species & Trophic guild & $\mathrm{N}$ & $\delta^{13} \mathrm{C} \pm \mathrm{SD}$ & $\delta^{15} \mathrm{~N} \pm \mathrm{SD}$ \\
\hline \multicolumn{6}{|l|}{ Annelida } \\
\hline \multirow[t]{2}{*}{ Polychaeta } & Aphrodita sp. & $\mathrm{SDF}$ & 3 & $-15.24 \pm 0.45$ & $10.39 \pm 0.58$ \\
\hline & Polynoidae sp. & $\mathrm{SDF}$ & 2 & $-15.84 \pm 0.04$ & $9.80 \pm 0.35$ \\
\hline \multicolumn{6}{|l|}{ Cnidaria } \\
\hline Anthozoa & Anthomastus agaricus & $\mathrm{SF}$ & 3 & $-15.75 \pm 0.11$ & $9.80 \pm 0.16$ \\
\hline \multicolumn{6}{|l|}{ Echinodermata } \\
\hline \multirow{6}{*}{ Asteroidea } & Hyphalaster inermis & SSDF & 3 & $-16.14 \pm 0.06$ & $11.86 \pm 0.79$ \\
\hline & Porcellanaster cerulus & SSDF & 3 & $-15.19 \pm 0.72$ & $11.10 \pm 0.86$ \\
\hline & Plutonaster bifrons & SSDF & 3 & $-14.87 \pm 0.68$ & $10.72 \pm 0.29$ \\
\hline & Plutonaster sp. & SSDF & 3 & $-14.34 \pm 0.31$ & $12.13 \pm 0.35$ \\
\hline & Hymenaster membranaceus & $\mathrm{SDF}$ & 3 & $-15.52 \pm 0.14$ & $9.20 \pm 0.22$ \\
\hline & Freyella sp. & $\mathrm{SF}$ & 3 & $-15.19 \pm 0.46$ & $14.93 \pm 0.29$ \\
\hline \multirow[t]{10}{*}{ Holothuroidea } & Staurocucumis abyssorum & $\mathrm{SDF}$ & 3 & $-16.31 \pm 0.08$ & $7.73 \pm 0.15$ \\
\hline & Benthothuria funebris & $\mathrm{SDF}$ & 3 & $-15.89 \pm 0.16$ & $10.78 \pm 0.20$ \\
\hline & Benthodytes gosarsi & $\mathrm{SDF}$ & 3 & $-15.92 \pm 0.36$ & $9.60 \pm 0.15$ \\
\hline & Ellipinion delagei & $\mathrm{SDF}$ & 3 & $-15.27 \pm 0.35$ & $9.49 \pm 0.39$ \\
\hline & Gephirothuria alcocki & SSDF & 3 & $-15.25 \pm 0.66$ & $15.47 \pm 1.50$ \\
\hline & Paelopatides grisea & SDF & 3 & $-16.58 \pm 1.03$ & $11.36 \pm 0.34$ \\
\hline & Peniagone islandica & $\mathrm{SDF}$ & 3 & $-15.96 \pm 0.46$ & $8.83 \pm 0.46$ \\
\hline & Pseudostichopus aff peripatus & SSDF & 3 & $-16.47 \pm 0.16$ & $11.39 \pm 0.18$ \\
\hline & Psychropotes depressa & SDF & 3 & $-15.29 \pm 0.33$ & $13.16 \pm 0.67$ \\
\hline & Molpadia musculus & SSDF & 3 & $-16.21 \pm 0.08$ & $15.78 \pm 1.43$ \\
\hline \multicolumn{6}{|l|}{ Crustacea } \\
\hline \multirow[t]{4}{*}{ Decapoda } & Acanthephyra sp. & $\mathrm{P}$ & 3 & $-18.27 \pm 0.22$ & $9.08 \pm 0.25$ \\
\hline & Glyphocrangon sculpta & SDF-PS & 3 & $-15.93 \pm 0.13$ & $12.06 \pm 0.07$ \\
\hline & Munidopsis rostrata & $\mathrm{SDF}-\mathrm{PS}$ & 3 & $-15.67 \pm 0.63$ & $10.91 \pm 0.37$ \\
\hline & Stereomastis nana & PS & 2 & $-17.87 \pm 0.22$ & $9.29 \pm 0.23$ \\
\hline Lophogastrida & Gnathophausia zoea & $\mathrm{P}$ & 3 & $-18.93 \pm 0.26$ & $10.60 \pm 0.44$ \\
\hline Pendunculata & Stalked barnacle & $\mathrm{SF}$ & 3 & $-17.73 \pm 0.36$ & $12.39 \pm 0.48$ \\
\hline \multicolumn{6}{|l|}{ Mollusca } \\
\hline \multirow[t]{2}{*}{ Gastropoda } & Gastropoda sp. 1 & $\mathrm{SDF}$ & 3 & $-14.28 \pm 0.03$ & $11.50 \pm 0.34$ \\
\hline & Gastropoda sp. 2 & $\mathrm{SDF}$ & 3 & $-15.44 \pm 0.15$ & $10.60 \pm 0.42$ \\
\hline \multicolumn{6}{|l|}{ Sipuncula } \\
\hline Sipunculidea & Sipunculus norvegicus & SSDF & 3 & $-14.70 \pm 0.08$ & $14.50 \pm 0.21$ \\
\hline \multicolumn{6}{|l|}{ Pisces } \\
\hline \multirow[t]{10}{*}{ Osteichthyes } & Antimora rostrata & PS & 3 & $-17.93 \pm 0.22$ & $12.53 \pm 0.83$ \\
\hline & Bathysaurus ferox & PS & 3 & $-17.53 \pm 0.92$ & $13.13 \pm 2.42$ \\
\hline & Coryphaenoides armatus & PS & 4 & $-16.47 \pm 0.90$ & $12.99 \pm 0.33$ \\
\hline & Coryphaenoides brevibarbis & PS & 3 & $-17.56 \pm 0.12$ & $12.29 \pm 0.54$ \\
\hline & Coryphaenoides carapinus & PS & 3 & $-16.28 \pm 0.29$ & $12.57 \pm 0.12$ \\
\hline & Coryphaenoides leptolepis & PS & 3 & $-17.24 \pm 0.09$ & $13.29 \pm 0.64$ \\
\hline & Halosauropsis macrochir & PS & 3 & $-17.07 \pm 0.67$ & $13.11 \pm 0.96$ \\
\hline & Histiobranchius bathybius & PS & 6 & $-17.76 \pm 0.37$ & $11.47 \pm 1.07$ \\
\hline & Polyacanthonotus challengeri & PS & 3 & $-15.79 \pm 0.36$ & $13.67 \pm 0.40$ \\
\hline & Spectrunculus grandis & PS & 3 & $-17.39 \pm 0.64$ & $12.73 \pm 1.07$ \\
\hline
\end{tabular}

(Polunin et al. 2001) and North Pacific abyssal (Drazen et al. 2008b) trophic assemblages have strong, positive relationships between $\delta^{15} \mathrm{~N}$ and $\delta^{13} \mathrm{C}$ values, suggesting a linear food chain dependent on a single photosynthetic energy source (Polunin et al. 2001, Drazen et al. 2008b). The trophic assemblage at the northern section of the MAR had a positive relationship between $\delta^{15} \mathrm{~N}$ and $\delta^{13} \mathrm{C}$ which suggested a single trophic pathway. However, a weak association between $\delta^{15} \mathrm{~N}$ and $\delta^{13} \mathrm{C}$ values occurred at the southern station in 2007 and 2009 and was more akin to that found at the Porcupine Abyssal Plain (PAP) (Iken et al. 2001), which suggested the southern MAR station had a complex food web with $>1$ trophic pathway. Separation of the MAR benthic assemblages into phytodetritus 
and predator-scavenger food chains revealed strong positive relationships between $\delta^{15} \mathrm{~N}$ and $\delta^{13} \mathrm{C}$ at all stations, except the predator-scavenger food chain at the southern station in 2007. Large scavenging and predatory fishes including Histiobranchus bathybius, Bathysaurus ferox and Spectunculus grandis were absent in the trawls, but this is likely an issue of sample collection as they do occur on the MAR between the Azores and the CGFZ (Bergstad et al. 2008). In $2009 H$. bathybius, B. ferox and $S$. grandis, along with Coryphaenoides carapinus and C. leptolepis had $\delta^{13} \mathrm{C}$ and $\delta^{15} \mathrm{~N}$ values intermediate to those measured for Acanthephyra sp. and $C$. armatus. Therefore, their absence in 2007 potentially resulted in the lack of a significant relationship between $\delta^{15} \mathrm{~N}$ and $\delta^{13} \mathrm{C}$.

The MAR predator-scavenger food chain comprised fishes and crustaceans, which in general were ${ }^{13} \mathrm{C}$ depleted relative to the benthic deposit feeders. The $\delta^{13} \mathrm{C}$ values of pelagic organisms in the top $1000 \mathrm{~m}$ over the MAR range from -25 to $-17 \%$ (Petursdottir et al. 2008, Letessier et al. 2012), indicating that MAR bentho-pelagic predators and scavengers may feed on these organisms. Bathypelagic fish biomass is also higher in the vicinity of the MAR and may provide an important food source for bentho-pelagic predators and scavengers (Sutton et al. 2008). However, there were differences in the stable isotope values among the various fishes within the predator-scavenger food chain, which may indicate differences in trophic niches as well as connectivity to the phytodetritus food chain. For example, the larger scavengers Antimora rostrata and Coryphaenoides armatus have similar foraging strategies (Collins et al. 2005), but there were differences in stable isotope values between these species on the MAR. A. rostrata and C. armatus from the Porcupine Seabight differ in certain fatty acids which is thought to reflect a greater proportion of benthic organisms in the diet of C. armatus (Stowasser et al. 2009). If there is a similar scenario on the MAR then it might explain the greater $\delta^{13} \mathrm{C}$ and $\delta^{15} \mathrm{~N}$ values, which were found in C. armatus.

Diets and behaviour of small benthic deep-sea fish, e.g. Polyacanthonotus challengeri and Halosauropsis macrochir, and those not attracted to carrion, e.g. Bathysaurus ferox and Coryphaenoides carapinus, are less well understood. H. macrochir, B. ferox and C. brevibarbis had similar $\delta^{13} \mathrm{C}$ values to the larger scavengers, but $P$. challengeri and $C$. carapinus were enriched in ${ }^{13} \mathrm{C}$ relative to these fishes. The $\delta^{13} \mathrm{C}$ and $\delta^{15} \mathrm{~N}$ values of $P$. challengeri and C. carapinus suggested consumers higher in the phytodetritus food chain, indicating that some fish species may gain a certain proportion of their nutrition from benthic invertebrates. Stomach content analysis within the genus Polyacanthonotus indicates that it forages on epibenthic invertebrates and polychaetes (Carrasson \& Matallanas 2002). In contrast, C. brevibarbis and H. macrochir stomachs contain copepods, decapods, fish, large amounts of unidentified material and only traces of epibenthic invertebrates, indicating a diet dominated by bathypelagic organisms (Mauchline \& Gordon 1984, Gordon \& Duncan 1987).

Crustaceans were the other main taxonomic group that comprised the predator-scavenger food chain. Acanthephyra sp. and Gnathophausia zoea had $\delta^{13} \mathrm{C}$ values related to a pelagic energy source and were consistently lower in $\delta^{15} \mathrm{~N}$ than deep-sea fishes. Acanthephyra sp. and G. zoea may have been caught during the ascent or descent of the OTSB because they occur at meso-pelagic depths above Stn S and Stn N (Letessier et al. 2012). However, the genus Acanthephyra covers a wide depth range (420 to $4000 \mathrm{~m}$; Sarda et al. 2005), and species are seen in baited lander experiments at bathyal and abyssal sites (Jones et al. 2003). While G. zoea occurs at depths $>2500 \mathrm{~m}$ on the MAR (Aas 2006) and is also found within the stomachs of bentho-pelagic fishes below its peak abundance on continental margins (Mauchline \& Gordon 1991). Acanthephyra sp. and G. zoea may form part of the predator-scavenger food chain by impinging on the slopes or sinking as carrion. The benthic crustaceans Glyphocrangon sculpta and Munidopsis rostrata had higher $\delta^{13} \mathrm{C}$ values compared to other species of crustaceans at Stn $\mathrm{S}$ and to G. sculpta and M. bermudezi at Stn N. Bathyal galatheids, including Munidopsis spp., have a mixed diet of detritus and infauna (Cartes et al. 2007) and are observed feeding at marine carrion (Kemp et al. 2006). The trophic roles of G. sculpta and M. rostrata may vary between the 2 stations depending on the availability of detrital, infaunal and carrion food sources.

Deposit feeders are dependent on phytodetritus once it arrives on the seafloor and therefore may utilise photosynthetic primary production at a different stage of degradation and mineralisation to that of deep-sea mobile predators and scavengers. There was a large difference in $\delta^{13} \mathrm{C}$ values between MAR deposit feeders and sediments. At Stn S, primary deposit feeders were enriched in ${ }^{13} \mathrm{C}$ relative to the mean surface sediment by $4.55 \%$ (2007) and $4.18 \%$ (2009) and at Stn N by $3.59 \%$, which is greater than the mean trophic shift of between 0.5 and $1 \%$ that is used in many trophic studies. The difference between 
sediment and $\mathrm{SDF} \delta^{13} \mathrm{C}$ values on the MAR is greater than in other deep-sea areas, as differences between sediment and SDF range from $\sim 1.50 \%$ on the North Pacific Abyssal Plain (Drazen et al. 2008b) to 2.00\% on the Pakistan Margin (Jeffreys et al. 2009). At Stn $\mathrm{N}$ in 2007 the foraminifera Rhizammina sp. had an isotopic value between the surface sediment layer and the SDF with the lowest $\delta^{13} \mathrm{C}$ values, which suggested processing of the sediment before it was consumed by the deposit feeding megafauna. Bacterial remineralisation of the organic matter pool will have an effect on the material that is ingested by the deposit feeders, as bacterial production can have $\delta^{13} \mathrm{C}$ values $2.3 \%$ greater than the carbon source (Coffin et al. 1990). This may partially explain large differences between sediment and deposit feeders (Lovvorn et al. 2005) as an increase in the amount of organic matter arriving at the sediment surface can result in a $30 \%$ increase in bacterially derived organic matter (Mayer 1993).

The relationship between $\delta^{15} \mathrm{~N}$ values of the sediment and deposit feeders was complex on the MAR. $\delta^{15} \mathrm{~N}$ values of surface deposit feeders were between 0.58 and $2.35 \%$ greater than the means of the surface sediments at both stations in 2007. In 2009 surface deposit feeders' $\delta^{15} \mathrm{~N}$ values were $11.07 \%$ lower than the means of surface sediment. At Stn $\mathrm{S}, \delta^{15} \mathrm{~N}$ values of some sediments did not fall within the 0 to $14 \%$ range of recently accumulated marine sediments (Hoefs 2004), with values as low as $-0.74 \%$ and as high as $23.14 \%$. The negative $\delta^{15} \mathrm{~N}$ values possibly may be an artefact of low total nitrogen (TN) concentration within the sediment samples. However, the mass of TN within the sediment samples was above the level of detection of the analytical system, which indicates the negative $\delta^{15} \mathrm{~N}$ values at Stn $\mathrm{S}$ in 2007 are likely to be accurate. Negative $\delta^{15} \mathrm{~N}$ values for marine sediments are rare, and they are linked to pelagic processes rather than those occurring after deposition (Rau et al. 1987). However, the $\delta^{15} \mathrm{~N}$ values of the sediment trap moored $100 \mathrm{~m}$ above the sea floor ranged from 0.98 to $2.93 \%$, indicating that enrichment of ${ }^{15} \mathrm{~N}$ occurred below this point. Understanding the different nitrogen pools within the sediment and the degree of organic matter reworking by heterotrophic micro-organisms or bacteria was outside the scope of the present study, and we did not isolate different inorganic species, e.g. $\mathrm{NH}_{4}{ }^{+}$and $\mathrm{NO}_{3}{ }^{-}$, or organic nitrogen fractions from the sediment. The MAR sediment $\delta^{15} \mathrm{~N}$ values represented the TN pool, which may not be representative of organic nitrogen within the sediment (Horsfall \& Wolff 1997) and that assimilated by deposit feeders.
The $\delta^{13} \mathrm{C}$ and $\delta^{15} \mathrm{~N}$ values of SDF and SSDF represent a trophic spectrum, where consumers utilise different biochemical fractions within the sediment. Phytoplankton polyunsaturated fatty acids (PUFAs), for example, in the holothurians Staurocucumis abyssorum and Peniagone vitrea and the asteroid Hymenaster membranaceus indicate a heavy dependence on 'fresh' phytodetritus (Howell et al. 2003, Drazen et al. 2008a). Low $\delta^{13} \mathrm{C}$ and $\delta^{15} \mathrm{~N}$ values in $S$. abyssorum, Peniagone spp. and $H$. membranaceus in relation to other organisms (this study, Iken et al. 2001, Drazen et al. 2008b) suggest that these echinoderms feed at the surface sediment layer. The $\delta^{13} \mathrm{C}$ and $\delta^{15} \mathrm{~N}$ values of $\mathrm{SSDF}$, including the asteroid Hyphalaster inermis, holothurian Molpadia musculus and sipunculan Sipunculus norvegicus, which ingest sediment deep below the surface, were amongst the highest for the MAR. Similarly, Molpadia blakei and a sipunculan have some of the highest $\delta^{15} \mathrm{~N}$ values of organisms collected at the PAP (Iken et al. 2001). $\delta^{13} \mathrm{C}$ and $\delta^{15} \mathrm{~N}$ values of marine sediment generally increase with depth, indicating a more refractory food source, as well as a concurrent decrease in the percent TN (Cowie et al. 2009). Isotopic discrimination can depend on nitrogen availability, with trophic discriminations of up to $~ 6 \%$ occurring when food is nitrogen deficient (Adams \& Sterner 2000). Therefore, the high $\delta^{15} \mathrm{~N}$ values of SSDF may reflect metabolic processes of feeding on sediment with lower nitrogen concentration, as well as ingesting a food source more enriched in ${ }^{15} \mathrm{~N}$ relative to that consumed by SDF. Furthermore, bacterial 18:1 fatty acid isomers have been detected in high concentrations in $H$. inermis (Howell et al. 2003) and M. blakei (Ginger et al. 2000), indicating ingestion of large amounts of bacterial biomass. Trophic discrimination between food source and bacteria can be as large as $22 \%$ depending on the nitrogen source (Macko \& Estep 1984), which may further explain such high $\delta^{15} \mathrm{~N}$ values in SSDF. Without a better understanding of trophic discrimination in deep-sea deposit feeders ingesting sediment with different nitrogen content and the potential role of bacterial nutrition, it will not be possible to ascertain the trophic position of deposit feeders.

In a number of cases, there were large differences between deposit feeders with very similar $\delta^{13} \mathrm{C}$ values. For example, Molpadia musculus had $\delta^{15} \mathrm{~N}$ values that were $\sim 7 \%$ greater than in Staurocucumis abyssorum and Peniagone islandica at Stn S in 2009, while Sipunculus norvegicus was ${ }^{15} \mathrm{~N}$ enriched by $5.48 \%$ compared to Benthothuria funebris at Stn N in 2007. However, $\delta^{13} \mathrm{C}$ values only differed by $0.3 \%$ 
between these species, which indicated they assimilated similarly labile carbon sources, but the higher $\delta^{15} \mathrm{~N}$ values suggested that $M$. musculus and $S$. norvegicus assimilated a more refractory nitrogen source. Examining the $\delta^{13} \mathrm{C}$ and $\delta^{15} \mathrm{~N}$ values of amino acids within a deposit feeder's tissue may provide insight into the degree of reworking of the organic matter within the sediment before it is ingested. Total hydrolysable amino acids are potentially an important source of organic carbon and nitrogen to deepsea deposit feeders (Horsfall \& Wolff 1997). In the case of nitrogen, the trophic discrimination of specific amino acids can be negligible (e.g. phenylalanine), providing basal resource information, while others can be $>9 \%$ (e.g. glutamic acid) (McClelland \& Montoya 2002, Styring et al. 2010). Thus, the relative difference between $\delta^{15} \mathrm{~N}$ values of amino acids that undergo negligible and large trophic discrimination are hypothesised to provide information on relative trophic position (Chikaraishi et al. 2009), but in deposit feeders this may indicate the degree of previous heterotrophic reworking of amino acids within the sediment before assimilation. Compound-specific amino acid stable isotope analysis (CSAA-SIA) may therefore provide higher resolution information on the organic nitrogen compounds assimilated by deposit feeders and indicate whether further trophic pathways exist within the benthic deposit feeding assemblage.

\section{CONCLUSIONS}

The trophic assemblage of the MAR is broadly similar to other deep-sea habitats and is ultimately dependent on photosynthetic primary production being transported to the seafloor. The stable isotopic data indicated that there may be 2 trophic pathways: (1) mobile predator and scavenging fishes and crustaceans linked to aggregations of meso- and bathypelagic biomass associated with the MAR (Sutton et al. 2008) and (2) benthic invertebrates dependent on the downward flux of phytodetritus. In fact these 2 trophic pathways will be interconnected at various stages of organic matter recycling within the water column and benthos as organic matter is ingested, processed and excreted, becoming available to different trophic guilds. Therefore, the predator-scavenger and phytodetrital food chains suggested within the current paper potentially represent the dominant but not exclusive trophic pathways for highly mobile bentho-pelagic fishes and crustaceans or benthic invertebrates, respectively.
The MAR also highlights some interesting depositsediment trophic interactions. The greater spread of sediment $\delta^{15} \mathrm{~N}$ values at the southern station compared to the north, but similar spread in faunal values, suggests that bulk sediment or $\mathrm{TN} \delta^{15} \mathrm{~N}$ values may not be reflective or too crude a measure to understand the nitrogen sources utilised by the deposit feeding fauna. This would help to explain why other studies have observed varying isotopic differences between deposit feeders and surface sediments (Lovvorn et al. 2005, Drazen et al. 2008b, Mincks et al. 2008, Jeffreys et al. 2009). Further exploration at a finer biochemical level using CSAASIA to examine differences in $\delta^{15} \mathrm{~N}$ values of deposit feeders may shed more light on nitrogen cycling within the sediment and whether benthic deposit feeders are utilising similar nitrogen sources.

Acknowledgements. We thank the following for their help throughout this project: Prof I. G. Priede for allowing us to participate in the NERC funded ECOMAR (NE/C512961/1) research surveys JC011 and JC037 and providing comments during the development of the manuscript; the scientists, officers and crew who helped with sample collection and identification onboard and after JC011 and JC037; Dr C. J. Sweeting for initial discussions on stable isotope analysis; and Dr T. Schimmield and Dr R. Abell for providing sediment trap samples. The work was funded through NERC Research Grants EK127-10/08 and EK150-12/09 to B.D.W. and NERC studentship (NE/F010664/1) to W.D.K.R. We also thank the 3 anonymous reviewers, whose comments and suggestions helped to improve the manuscript.

\section{LITERATURE CITED}

Aas PO (2006) The distribution of Lophogastrida (Crustacea) along the Mid-Atlantic Ridge. University of Bergen, Bergen

Adams TS, Sterner RW (2000) The effect of dietary nitrogen content on trophic level ${ }^{15} \mathrm{~N}$ enrichment. Limnol Oceanogr 45:601-607

Angel MV (1997) Pelagic biodiversity. In: Ormond RFG, Gage JD, Angel MV (eds) Marine biodiversity. Cambridge University Press, New York

Bergmann M, Dannheim J, Bauerfeind E, Klages M (2009) Trophic relationships along a bathymetric gradient at the deep-sea observatory HAUSGARTEN. Deep-Sea Res I 56:408-424

Bergstad OA, Godo OR (2003) The pilot project 'Patterns and processes of the ecosystems of the northern Mid-Atlantic': aims, strategy and status. Oceanol Acta 25:219-226

Bergstad OA, Menezes G, Hoines AS (2008) Demersal fish on a mid-ocean ridge: distribution patterns and structuring factors. Deep-Sea Res II 55:185-202

Bicknell AWJ, Campbell M, Knight ME, Bilton DT, Newton J, Votier SC (2011) Effects of formalin preservation on stable carbon and nitrogen isotope signatures in calanoid copepods: implications for the use of Continuous Plankton Recorder Survey samples in stable isotope analyses. Rapid Commun Mass Spectrom 25:1794-1800 
Billett DSM (1991) Deep-sea holothurians. Oceanogr Mar Biol Annu Rev 29:259-317

Billett DSM, Lampitt RS, Rice AL, Mantoura RFC (1983) Seasonal sedimentation of phytoplankton to the deep-sea benthos. Nature 302:520-522

Bosley KL, Wainright SC (1999) Effects of preservatives and acidification on the stable isotope ratios $\left(\mathrm{N}^{15}: \mathrm{N}^{14}, \mathrm{C}^{13}\right.$ : $\mathrm{C}^{12}$ ) of two species of marine animals. Can J Fish Aquat Sci 56:2181-2185

Burd BJ, Thomson RE, Jamieson GS (1992) Composition of a deep scattering layer overlying a mid-ocean ridge hydrothermal plume. Mar Biol 113:517-526

> Carrasson M, Matallanas J (2002) Feeding strategies of Polyacanthonotus rissoanus (Pisces: Notacanthidae) in the deep western Mediterranean. J Mar Biol Assoc UK 82:665-671

> Cartes JE, Huguet C, Parra S, Sanchez F (2007) Trophic relationships in deep-water decapods of Le Danois bank (Cantabrian Sea, NE Atlantic): trends related with depth and seasonal changes in food quality and availability. Deep-Sea Res I 54:1091-1110

> Chikaraishi Y, Ogawa NO, Kashiyama Y, Takano Y and others (2009) Determination of aquatic food-web structure based on compound-specific nitrogen isotopic composition of amino acids. Limnol Oceanogr Methods 7: 740-750

Coffin RB, Velinsky DJ, Devereux R, Price WA, Cifuentes LA (1990) Stable carbon isotope analysis of nucleic-acids to trace sources of dissolved substrates used by estuarine bacteria. Appl Environ Microbiol 56:2012-2020

Collins MA, Bailey DM, Ruxton GD, Priede IG (2005) Trends in body size across an environmental gradient: a differential response in scavenging and non-scavenging demersal deep-sea fish. Proc Biol Sci 272:2051-2057

Connolly RM, Guest MA, Melville AJ, Oakes JM (2004) Sulfur stable isotopes separate producers in marine foodweb analysis. Oecologia 138:161-167

Copley JTP, Tyler PA, Sheader M, Murton BJ, German CR (1996) Megafauna from sublittoral to abyssal depths along the Mid-Atlantic Ridge south of Iceland. Oceanol Acta 19:549-559

> Cowie GL, Mowbray S, Lewis M, Matheson H, McKenzie R (2009) Carbon and nitrogen elemental and stable isotopic compositions of surficial sediments from the Pakistan margin of the Arabian Sea. Deep-Sea Res II 56: 271-282

> Drazen JC, Phleger CF, Guest MA, Nichols PD (2008a) Lipid, sterols and fatty acid composition of abyssal holothurians and ophiuroids from the North-East Pacific Ocean: food web implications. Comp Biochem Physiol B 151:79-87

> Drazen JC, Popp BN, Choy CA, Clemente T, De Forest L, Smith KL (2008b) Bypassing the abyssal benthic food web: macrourid diet in the eastern North Pacific inferred from stomach content and stable isotopes analyses. Limnol Oceanogr 53:2644-2654

Erickson KL, Macko SA, Van Dover CL (2009) Evidence for a chemoautotrophically based food web at inactive hydrothermal vents (Manus Basin). Deep-Sea Res II 56: 1577-1585

> Fabri MC, Bargain A, Briand P, Gebruk A, Fouquet Y, Morineaux M, Desbruyeres D (2011) The hydrothermal vent community of a new deep-sea field, Ashadze-1, $12^{\circ} 58^{\prime} \mathrm{N}$ on the Mid-Atlantic Ridge. J Mar Biol Assoc UK 91:1-13
Fry B (1988) Food web structure on Georges Bank from stable $\mathrm{C}, \mathrm{N}$, and $\mathrm{S}$ isotopic compositions. Limnol Oceanogr 33:1182-1190

Gage JD, Bett BJ (2005) Deep-sea benthic sampling. In: Holmes NA, McIntyre AD (eds) Methods for the study of the marine benthos. Blackwell Scientific Publications, Oxford

Gartner JV, Crabtree RE, Sulak KJ (1997) Feeding at depth. In: Randall DJ, Farrell AP (eds) Deep-sea fishes. Academic Press Limited, London, p 115-192

Gebruk AV, Galkin SV, Vereshchaka AL, Moskalev LI, Southward AJ (1997) Ecology and biogeography of the hydrothermal vent fauna of the Mid-Atlantic Ridge. Adv Mar Biol 32:93-144

> Ginger ML, Santos V, Wolff GA (2000) A preliminary investigation of the lipids of abyssal holothurians from the north-east Atlantic Ocean. J Mar Biol Assoc UK 80: 139-146

Gooday AJ (2002) Biological responses to seasonally varying fluxes of organic matter to the ocean floor: a review. J Oceanogr 58:305-332

> Gordon JDM, Duncan JAR (1987) Deep-sea bottom-living fishes at two repeat stations at 2200 and $2900 \mathrm{~m}$ in the Rockall Trough, northeastern Atlantic Ocean. Mar Biol 96:309-325

> Hesslein RH, Hallard KA, Ramlal P (1993) Replacement of sulfur, carbon, and nitrogen in tissue of growing broad whitefish (Coregonus nasus) in response to a change in diet traced by $\delta^{34} \mathrm{~S}, \delta^{13} \mathrm{C}$ and $\delta^{15} \mathrm{~N}$. Can J Fish Aquat Sci 50:2071-2076

Hoefs J (2004) Stable isotope geochemistry. Springer, Berlin

Horsfall IM, Wolff GA (1997) Hydrolysable amino acids in sediments from the Porcupine Abyssal Plain, northeast Atlantic Ocean. Org Geochem 26:311-320

Howell KL, Pond DW, Billett DSM, Tyler PA (2003) Feeding ecology of deep-sea seastars (Echinodermata: Asteroidea): a fatty-acid biomarker approach. Mar Ecol Prog Ser 255:193-206

Iken K, Brey T, Wand U, Voigt J, Junghans P (2001) Food web structure of the benthic community at the Porcupine Abyssal Plain (NE Atlantic): a stable isotope analysis. Prog Oceanogr 50:383-405

Jangoux M (1982) Food and feeding mechanisms: Asteroidea. In: Jangoux M, Lawrence JM (eds) Echinoderm nutrition. A. A. Balkema, Rotterdam, p 117-159

> Jeffreys RM, Wolff GA, Murty SJ (2009) The trophic ecology of key megafaunal species at the Pakistan Margin: evidence from stable isotopes and lipid biomarkers. DeepSea Res I 56:1816-1833

> Jones EG, Tselepides A, Bagley PM, Collins MA, Priede IG (2003) Bathymetric distribution of some benthic and benthopelagic species attracted to baited cameras and traps in the deep eastern Mediterranean. Mar Ecol Prog Ser 251:75-86

Juteau T, Maury R (1999) The oceanic crust, from accretion to mantle recycling. Praxis Publishing, Chichester

Kaehler S, Pakhomov EA (2001) Effects of storage and preservation on the $\delta^{13} \mathrm{C}$ and $\delta^{15} \mathrm{~N}$ signatures of selected marine organisms. Mar Ecol Prog Ser 219:299-304

> Kemp KM, Jamieson AJ, Bagley PM, McGrath H, Bailey DM, Collins MA, Priede IG (2006) Consumption of large bathyal food fall, a six month study in the NE Atlantic. Mar Ecol Prog Ser 310:65-76

Letessier TB, Pond DW, McGill RAR, Reid WDK, Brierley AS (2012) Trophic interaction of invertebrate micronekton 
on either side of the Charlie Gibbs Fracture Zone / Subpolar Front of the Mid-Atlantic Ridge. J Mar Syst 94: 174-184

Longhurst AR (2006) Ecological geography of the sea. Elsevier, Amsterdam

Lovvorn JR, Cooper LW, Brooks ML, De Ruyck CC, Bump JK, Grebmeier JM (2005) Organic matter pathways to zooplankton and benthos under pack ice in late winter and open water in late summer in the north-central Bering Sea. Mar Ecol Prog Ser 291:135-150

Macko SA, Estep MLF (1984) Microbial alteration of stable nitrogen and carbon isotopic compositions of organic matter. Org Geochem 6:787-790

Martinez-Vicente V, Tilstone GH, Sathyendranath S, Miller PI, Groom SB (2012) Contributions of phytoplankton and bacteria to the optical backscattering coefficient over the Mid-Atlantic Ridge. Mar Ecol Prog Ser 445:37-51

> Mauchline J, Gordon JDM (1984) Diets and bathymetric distributions of the macrourid fish of the Rockall Trough, northeastern Atlantic Ocean. Mar Biol 81:107-121

Mauchline J, Gordon JDM (1991) Oceanic pelagic prey of benthopelagic fish in the benthic boundary-layer of a marginal oceanic region. Mar Ecol Prog Ser 74: 109-115

Mayer LM (1993) Organic matter at the sediment-water interface. In: Engel MH, Macko SA (eds) Org Geochem. Plenum Press, New York, NY, p 171-184

> McClelland JW, Montoya JP (2002) Trophic relationships and the nitrogen isotopic composition of amino acids in plankton. Ecology 83:2173-2180

Merrett NR, Marshall NB (1980) Observations on the ecology of deep-sea bottom-living fishes collected off northwest Africa $\left(08^{\circ}-27^{\circ} \mathrm{N}\right)$. Prog Oceanogr 9:185-244

Mincks SL, Smith CR, Jeffreys RM, Sumida PYG (2008) Trophic structure on the West Antarctic Peninsula shelf: detritivory and benthic inertia revealed by $\delta^{13} \mathrm{C}$ and $\delta^{15} \mathrm{~N}$ analysis. Deep-Sea Res II 55:2502-2514

> Peterson BJ, Fry B (1987) Stable isotopes in ecosystem studies. Annu Rev Ecol Syst 18:293-320

> Petursdottir H, Gislason A, Falk-Petersen S, Hop H, Svavarsson J (2008) Trophic interactions of the pelagic ecosystem over the Reykjanes Ridge as evaluated by fatty acid and stable isotope analyses. Deep-Sea Res II 55:83-93

Polunin NVC, Morales-Nin B, Herod WE, Cartes JE, Pinnegar JK, Moranta J (2001) Feeding relationships in Mediterranean bathyl assemblages elucidated by carbon and nitrogen stable-isotope data. Mar Ecol Prog Ser 220: $13-23$

Post DM (2002) Using stable isotopes to estimate trophic position: models, methods, and assumptions. Ecology 83: 703-718

Post DM, Layman CA, Arrington DA, Takimoto G, Quattrochi J, Montana CG (2007) Getting to the fat of the matter: models, methods and assumptions for dealing with lipids in stable isotope analyses. Oecologia 152:179-189

Quinn GP, Keough MJ (2002) Experimental design and data analysis for biologists. Cambridge University Press, Cambridge

Rau GH, Arthur MA, Dean WE (1987) N15/N14 Variations in cretaceous Atlantic sedimentary sequences-implications for past changes in marine nitrogen biogeochemistry. Earth Planet Sci Lett 82:269-279

Reeves EP, Seewald JS, Saccocia P, Bach W and others (2011) Geochemistry of hydrothermal fluids from the PACMANUS, Northeast Pual and Vienna Woods hydro- thermal fields, Manus Basin, Papua New Guinea. Geochim Cosmochim Acta 75:1088-1123

> Roberts D, Moore HM (1997) Tentacular diversity in deepsea deposit-feeding holothurians: implications for biodiversity in the deep sea. Biodivers Conserv 6:1487-1505

Roth SE, Dymond J (1989) Transport and settling of organic material in a deep-sea hydrothermal plume-evidence from particle-flux measurements. Deep-Sea Res Part A 36:1237-1254

> Sarda F, Company J, Costa C (2005) A morphological approach for relating decapod crustacean cephalothorax shape with distribution in the water column. Mar Biol 147:611-618

Shanks WC (2001) Stable isotopes in seafloor hydrothermal systems: vent fluids, hydrothermal deposits, hydrothermal alteration, and microbial processes. In: Stable isotope geochemistry, Vol 43. Mineralogical Society of America, Washington, DC, p 469-525

Smith CR (1985) Food for the deep-sea-utilization, dispersal, and flux of nekton falls at the Santa Catalina Basin floor. Deep-Sea Res Part A 32:417-442

Smith KL, Baldwin RJ, Karl DM, Boetius A (2002) Benthic community responses to pulses in pelagic food supply: North Pacific Subtropical Gyre. Deep-Sea Res I 49: 971-990

Stowasser G, McAllen R, Pierce GJ, Collins MA, Moffat CF, Priede IG, Pond DW (2009) Trophic position of deep-sea fish-Assessment through fatty acid and stable isotope analyses. Deep-Sea Res I 56:812-826

Styring AK, Sealy JC, Evershed RP (2010) Resolving the bulk $\delta^{15} \mathrm{~N}$ values of ancient human and animal bone collagen via compound-specific nitrogen isotope analysis of constituent amino acids. Geochim Cosmochim Acta 74: 241-251

Sutton TT, Porteiro FM, Heino M, Byrkjedal I and others (2008) Vertical structure, biomass and topographic association of deep-pelagic fishes in relation to a mid-ocean ridge system. Deep-Sea Res II 55:161-184

Thode HG (1991) Sulfur isotopes in nature and the environment: an overview. In: Krouse HR, Grinenko VA (eds) Stable isotopes: natural and anthropogenic sulphur in the environment. Wiley, Chichester, p 1-26

> Tilstone G, Smyth T, Poulton A, Hutson R (2009) Measured and remotely sensed estimates of primary production in the Atlantic Ocean from 1998 to 2005. Deep-Sea Res II 56:918-930

Tyler PA, Gage JD, Paterson GJL, Rice AL (1993) Dietary constraints on reproductive periodicity in two sympatric deep-sea astropectinid seastars. Mar Biol 115:267-277

UNESCO (2009) Global open oceans and deep seabed (GOODS) biogeographic classification. IOC Technical Series 84, UNESCO-IOC, Paris

Van Dover CL (2000) The ecology of deep-sea hydrothermal vents. Princeton University Press, Chichester

- Wei CL, Rowe GT, Escobar-Briones E, Boetius A and others (2010) Global patterns and predictions of seafloor biomass using random forests. PLoS ONE 5:e15323

> Witte U, Wenzhofer F, Sommer S, Boetius A and others (2003) In situ experimental evidence of the fate of a phytodetritus pulse at the abyssal sea floor. Nature 424 : 763-766

Wolff GA, Billett DSM, Bett BJ, Holtvoeth J and others (2011) The effects of natural iron fertilisation on deep-sea ecology: the Crozet Plateau, southern Indian Ocean. PLoS ONE 6:e20697 